\title{
The Carbon Balance of Two Contrasting Mountain Forest Ecosystems in Switzerland: Similar Annual Trends, but Seasonal Differences
}

\author{
Sophia Etzold, ${ }^{1,3 *}$ Nadine K. Ruehr, ${ }^{2}$ Roman Zweifel, ${ }^{3}$ Matthias Dobbertin, ${ }^{3}$ \\ Andreas Zingg, ${ }^{3}$ Peter Pluess, ${ }^{1}$ Rudolf Häsler, ${ }^{3}$ Werner Eugster, ${ }^{1}$ and Nina \\ Buchmann $^{1}$
}

\begin{abstract}
${ }^{1}$ Institute of Agricultural Sciences, ETH Zürich, 8092 Zurich, Switzerland; ${ }^{2}$ Department of Forest Ecosystems \& Society, Oregon State University, Corvallis, Oregon 97331, USA; ${ }^{3}$ Swiss Federal Research Institute WSL, 8903 Birmensdorf, Switzerland
\end{abstract}

\begin{abstract}
Net ecosystem exchange (NEE) of two contrasting mountain forest types in Switzerland was measured by eddy covariance (EC) measurements at a montane mixed forest, the Lägeren forest, over 5 years (2005-2009), and at a subalpine coniferous forest, the Seehornwald in Davos, over 12 years (1997-2009). NEE was validated against annual carbon (C) storage estimates, based on biometric and soil respiration measurements as well as soil C modeling. Three different approaches were used: (1) calculation of net ecosystem production by quantifying $\mathrm{C}$ pools and fluxes, (2) assessment of change in wood biomass and soil $C$ storage $(\Delta C)$, and (3) application of biomass expansion factors.
\end{abstract}

Received 7 March 2011; accepted 11 August 2011; published online 13 September 2011

Author Contributions: SE, NKR, WE, and NB conceived or designed the study. SE, NKR, RZ, MD, AZ, and RH performed research. SE, NKR, $\mathrm{RZ}$, and RH analyzed data. RZ, MD, AZ, PP, and RH contributed new methods or models. SE and NKR wrote the article.

*Corresponding author; e-mail: sophia.etzold@ipw.agrl.ethz.ch
Although biometric estimates were sensitive to assumptions made for each method applied, they agreed well with measured NEE. Comparing 5 years of EC measurements available at both sites during 2005 and 2009 revealed that NEE, gross primary production (GPP), and total ecosystem respiration (TER) were larger at the Lägeren forest compared to the Davos forest, whereas soil respiration and soil $\mathrm{C}$ sequestration were of similar magnitudes. Both sites showed similar annual trends for NEE, GPP and TER, but different seasonal courses, due to different responses to environmental conditions (temperature, soil moisture, and radiation). Differences in the magnitude as well as in the seasonality of ecosystem $\mathrm{CO}_{2}$ exchange could mainly be attributed to tree phenology, productivity, and carbon allocation patterns, which are combined effects of tree type (broad-leaved vs. coniferous trees) and site-specific climatic conditions. Flux differences between the two mountain sites highlight the importance of considering the role of altitude in ecological studies and modeling.

Key words: biometric inventory; eddy covariance; mountain forest; NEE; NEP; soil respiration; soil carbon sequestration; modeling. 


\section{INTRODUCTION}

Mountains cover one quarter of the earth's land surface, of which $25 \%$ are forested (UNEP-WCMC 2009). Mountain forests are expected to be more strongly affected by climate change than lowland forests due to their sensitivity to warming (Schroeter and others 2005; IPCC 2007; Metzger and others 2008). In Switzerland, $30 \%$ of the land is currently covered by forests (SAEFL/WSL 2005), of which $60 \%$ grow on mountain slopes steeper than $22^{\circ}$ (Braendli 2010). Nevertheless, the Swiss forests are among the most productive forests in Europe. They sequester about three times more $\mathrm{C}$ per hectare than the average European forest and $60 \%$ more than the average forest of Central Europe (SAEFL/WSL 2005; Bolliger and others 2008). Currently, $142 \mathrm{Mt} \mathrm{C}$ are stored in the whole living tree biomass and $6 \mathrm{Mt} \mathrm{C}$ in the dead wood of Swiss forests (Braendli 2010). The carbon stocks of Swiss forest soils have been estimated at $120 \mathrm{Mt}$ C (Liski and others 2002). Thus, the Swiss mountain forests, as they represent two-thirds of the forested area in Switzerland, have obviously a large potential to sequester carbon. On the other hand, they hold huge amounts of $\mathrm{C}$ that may be released in case of further increases in extreme weather events (for example, heat waves, drought, flooding) as predicted to occur along with climate change (IPCC 2007).

The dynamics of mountain forests in response to climatic changes are, however, still very poorly understood, as most studies on the forest $\mathrm{C}$ cycle so far were conducted in boreal and temperate lowland forests (for example, Valentini and others 2000; Janssens and others 2003; Luyssaert and others 2007). But the often-made comparison between forests growing at high altitudes near the alpine tree line with those growing at high latitudes near the arctic timberline is typically flawed by important differences between environmental conditions at both extremes. Namely, the presence of permafrost at the arctic tree line leads to much shallower rooting depths. In addition, soil infiltration and risk of droughts may differ strongly between arctic and alpine localities, and differences in atmospheric nitrogen inputs due to differences in remoteness may result in differences in annual growth rates. In this study, we compare 5 years of simultaneous eddy covariance (EC) measurements conducted over two mountain forests that are representative for their altitudinal range in Switzerland, the Lägeren forest in the Jura Mountain range at $700 \mathrm{~m}$ a.s.l., and the Davos forest in the Eastern Swiss Alps at $1640 \mathrm{~m}$ a.s.l. Altitude can serve as a proxy for multiple factors characterizing a forest ecosystem, such as climatic conditions and growing season length, species composition and diversity, and the age of the individual trees. We ask whether productivity and $\mathrm{C}$ exchange patterns of forests can also be interpreted as a function of altitude.

The productivity of a terrestrial ecosystem can be assessed by micrometeorological, for example, EC, or by biometric methods. Half-hourly $\mathrm{CO}_{2}$ fluxes, measured by the EC technique, integrate over an entire ecosystem or a representative fraction of an ecosystem within a certain spatial extent, the socalled flux footprint. The sum of $\mathrm{CO}_{2}$ fluxes over longer periods is termed net ecosystem exchange (NEE) in the following. If measured over the same time period, the net ecosystem production (NEP) of a terrestrial ecosystem as can be determined from biometric measurements of single trees and soil respiration measurements should equal NEE measured by EC (Chapin and others 2006), when measured over short time scales, in the absence of fire, harvest, deposition and erosion, and under the assumption that loss or import of dissolved organic $\mathrm{C}$ in the aquatic phase is small (which is at least the case for forest ecosystems, see Kindler and others $2011)$.

Net ecosystem exchange, derived from EC, and NEP, derived from biometric measurements, are conceptually identical, but methodologically independent, and therefore also the sources of error are independent (Curtis and others 2002). Hence, the comparison of NEE with NEP helps to validate estimates of forests $\mathrm{C}$ storage (Kominami and others 2008; Keith and others 2009; Peichl and others 2010). This is thought to be especially important for EC measurements over non-ideal terrain, where uncertainties in EC budgets are expected to be larger than over flat ground, namely in cases where advection, intermittent turbulence and mesoscale effects cannot be neglected (Aubinet and others 2000; Aubinet 2008).

Furthermore, the assessment of the contribution and dynamics of the $\mathrm{C}$ storage of single forest compartments in relation to NEP helps to explain observed differences in $\mathrm{C}$ uptake patterns between ecosystems (Ehman and others 2002; Ohtsuka and others 2009). However, NEP and NEE include physiological processes that act on a wide range of time scales. Disagreements between NEP and NEE on shorter time scales (annually) were so far related to C storage and allocation processes (Black and others 2007), which become less prominent as the length of averaging period increases (Gough 
and others 2008b). To address the possible role of differences in time scales of the relevant processes we complemented our EC measurements at both forest sites with biometric estimates of NEP, which include a time period of 5 years at the Lägeren and 22 years at the Davos site. Comparing temporal and spatial variability of the two forests' net $\mathrm{C}$ uptake, assessed by the two different approaches, we aimed at (1) validating the $\mathrm{C}$ exchange estimates by EC of both mountain forests, (2) identifying the annual and seasonal patterns of $\mathrm{C}$ exchange of both forests, (3) explaining possible differences in forest net $\mathrm{C}$ uptake with differences in the individual forest compartment $\mathrm{C}$ pools and fluxes, and (4) relating possible differences in the $\mathrm{C}$ uptake of both forests to their different altitudinal ranges.

\section{Materials AND Methods}

\section{Study Sites}

The study was carried out at the Lägeren forest $(\mathrm{CH}-\mathrm{Lae})$ in the Jura Mountain range and at the
Davos Seehornwald (CH-Dav) forest in the Eastern Swiss Alps (Table 1). The Lägeren forest is representative of the montane zone of the Alps according to Ellenberg and Leuschner (2010), which ranges from region-specific 500 and $800 \mathrm{~m}$ a.s.l. up to 1,500 and $2,000 \mathrm{~m}$ a.s.l. The upper boundary is defined by the distribution limit of closed high forests. The montane forest zone is dominated by mixed broad-leaved and coniferous forests with beech and fir trees. The Davos Seehornwald belongs to the subalpine zone, which extends to the tree line at 2,000-2,100 $\mathrm{m}$ a.s.l in this region (1,700-2,400 m a.s.l. in the Swiss Alps). The term subalpine coniferous forest as defined for the Alpine region often corresponds to the internationally used term "high montane forest". It is dominated by spruce and pine trees and is characterized by trees in loose formation and the occurrence of krummholz. Continuous EC measurements from both sites are integrated in the global Fluxnet project database, and both sites belong to the Swiss National Air Pollution Monitoring Network (NABEL 2010).

Table 1. Environmental Characteristics of the Study Sites Lägeren and Davos

\begin{tabular}{|c|c|c|}
\hline & Lägeren & Davos \\
\hline Altitude (m) & 682 & 1,639 \\
\hline Latitude & $47^{\circ} 28^{\prime} 40.8^{\prime \prime} \mathrm{N}$ & $46^{\circ} 48^{\prime} 55.2^{\prime \prime} \mathrm{N}$ \\
\hline Longitude & $8^{\circ} 21^{\prime} 55.2^{\prime \prime} \mathrm{E}$ & $9^{\circ} 51^{\prime} 21.3^{\prime \prime} \mathrm{E}$ \\
\hline Slope $\left({ }^{\circ}\right)$ & 27 & \\
\hline Geographical region & Swiss Jura & Eastern Alps \\
\hline Altitudinal zone & Montane & Subalpine \\
\hline Mean annual air temperature $\left({ }^{\circ} \mathrm{C}\right)^{1}$ & 7.4 & 3.4 \\
\hline Mean annual precipitation sum $(\mathrm{mm})^{1}$ & 1000 & 1000 \\
\hline Vegetation & Mixed deciduous dominated forest & Coniferous forest \\
\hline Dominant tree species & $\begin{array}{l}\text { Fagus sylvatica L. } \\
\text { Picea abies (L.) Karst } \\
\text { Fraxinus excelsior L. } \\
\text { Acer pseudoplatanus L. }\end{array}$ & Picea abies (L.) Karst. \\
\hline Tree age of dominant trees (years) & $\begin{array}{l}\text { F.sylvatica: } 52-155 \\
\text { P.abies: } 105-185\end{array}$ & $240(200-390)$ \\
\hline Mean tree height of dominant trees (m) & 30.6 & 25 \\
\hline Max. leaf area index $\left(\mathrm{m}^{2} \mathrm{~m}^{-2}\right)$ & $1.7-5.5$ & 3.9 \\
\hline Understory & Allium ursinum L. & $\begin{array}{l}\text { Vaccinium myrtillus L. } \\
V . \text { gaultherioides L. } \\
\text { Sphagnum sp. }\end{array}$ \\
\hline $\mathrm{pH}$ & $4.0-7.5$ & $3.5-4.5$ \\
\hline Soil type ${ }^{2}$ & $\begin{array}{l}\text { Rendzic leptosols } \\
\text { Haplic cambisols }\end{array}$ & $\begin{array}{l}\text { Chromic cambisols } \\
\text { Rustic podsols }\end{array}$ \\
\hline Soil C stock $\left(\mathrm{kg} \mathrm{m}^{-2}\right)$ in $0-20 \mathrm{~cm}$ & $8.4-9.6^{3}$ & $9.2-11^{4}$ \\
\hline \multicolumn{3}{|c|}{$\begin{array}{l}{ }^{1} 20 \text { year average (1989-2009) calculated from MeteoSwiss (2010). } \\
{ }^{2} \text { After IUSS Working Group WRB (2007). } \\
{ }^{3} \text { Heim and others (2009). } \\
{ }^{J} \text { Jörg (2008). }\end{array}$} \\
\hline
\end{tabular}


The EC flux tower at the Lägeren study site is located at $682 \mathrm{~m}$ a.s.l. on the south facing slope of the Jura Mountain range, which marks the northern boundary of the Swiss Plateau. The forest stand is highly diverse with respect to tree species, diameter classes and tree age. The most abundant tree species are the European beech (Fagus sylvatica), ash (Fraxinus excelsior), and Norway spruce (Picea abies) (Eugster and others 2007). In spring, bear's garlic (Allium ursinum) forms a dense understory. The southern part of the footprint area has been sustainably managed according to the forest stewardship council (FSC) since 1998; the northern part is declared as a nature reserve, where tree harvesting was discontinued more than a decade ago. Footprint modeling after Kljun and others (2004) indicates that EC fluxes include both parts of the forest in relatively equal parts.

The Davos forest is located in the Eastern Swiss Alps at a height of $1,639 \mathrm{~m}$ a.s.l. The vegetation is highly dominated by Norway spruce trees (P. abies) with an only marginal role of larch trees (Larix decidua) with less than $1 \%$ abundance. The understory consists of dwarf shrubs of Vaccinium myrtillus and $V$.gaultherioides and dense moss mats. Site characteristics of both study sites are summarized in Table 1.

\section{Calculation of the Carbon Balance of the Forest Sites}

For both study sites forest inventory data within the footprint area of the EC flux tower were available. NEP from biometric and soil respiration measurements, as well as NEE from EC measurements were derived. For the Lägeren forest, two inventories were carried out in 2005 and 2009, and at Davos three inventories were carried out in 1988, 2006, and 2010. At the Lägeren, EC measurements were available from 2005 to 2009 and at Davos from 1997 to 2009.

\section{Calculation of the Carbon Pools and Fluxes for NEP Estimates}

The increment of live and dead material was estimated from the change in biomass between two forest inventories. To convert from tree biomass to carbon amounts, a fixed proportion of $50 \%$ C per $\mathrm{kg}$ of dry biomass was assumed (IPCC 2003).

\section{Tree Volume and Biomass}

Tree volume was estimated as a function of diameter at breast height (dbh) at Davos and of dbh, stem diameter at $7 \mathrm{~m}$ height and tree height at the
Lägeren forest. Species and region-specific formulas were used to convert from dbh to volume of branches and twigs as given in Table 2 . To convert from total tree volume into biomass, species specific conversion factors for wood density were applied according to Assmann (1986), except for Norway spruce in Davos. Here, analyses of the wood density of Norway spruce trees at Davos were carried out and yielded a conversion factor of 0.36 (Table 2).

\section{Foliage and Fruit Production}

We used dbh dependent functions to model the pools of foliage (Perruchoud and others 1999) and reproductive organs (Thuerig and others 2005). The gained annual estimates of foliage and reproductive litter for the Lägeren site agreed very well with measured litter fall (Ruehr and others 2010) averaged over the years 2006 and 2007 (difference $\pm 20 \mathrm{~g} \mathrm{C} \mathrm{m}^{-2} \mathrm{y}^{-1}$ ).

\section{Coarse and Fine Root Production}

Coarse root biomass of trees was estimated as a function of dbh (Table 2). Fine root biomass was calculated as $50 \%$ of foliage biomass (de Wit and others 2006). One main uncertainty in the fine root biomass calculation was the assumed turnover time of the fine roots. Very little is known about the turnover time of fine roots and reported values are highly variable, ranging from less than 1 year to decades (for example, Ehman and others 2002; de Wit and others 2006; Gough and others 2008b; Peichl and others 2010). Fine root turnover of the spruce trees at Davos was set to 3.33 years as found for spruce trees in Norway (de Wit and others 2006). At the Lägeren, fine root turnover was estimated from maximum fine root biomass (sequential coring) and annual fine root growth (ingrowth cores) to be 2.53 years (Ruehr, unpublished data). A recent study report that only $20 \%$ of the fine roots have a lifetime of less than 1 year, and about $80 \%$ have a lifetime of a decade or longer (Gaudinski and others 2010), which agree quite well with the turnover rates used in this study.

\section{Understory Production}

Understory litter biomass was estimated from earlier measurements at both study sites (Luescher 1991).

\section{Soil Respiration and its Component Fluxes}

Soil respiration (SR) chamber flux measurements were performed within the footprint area at the 


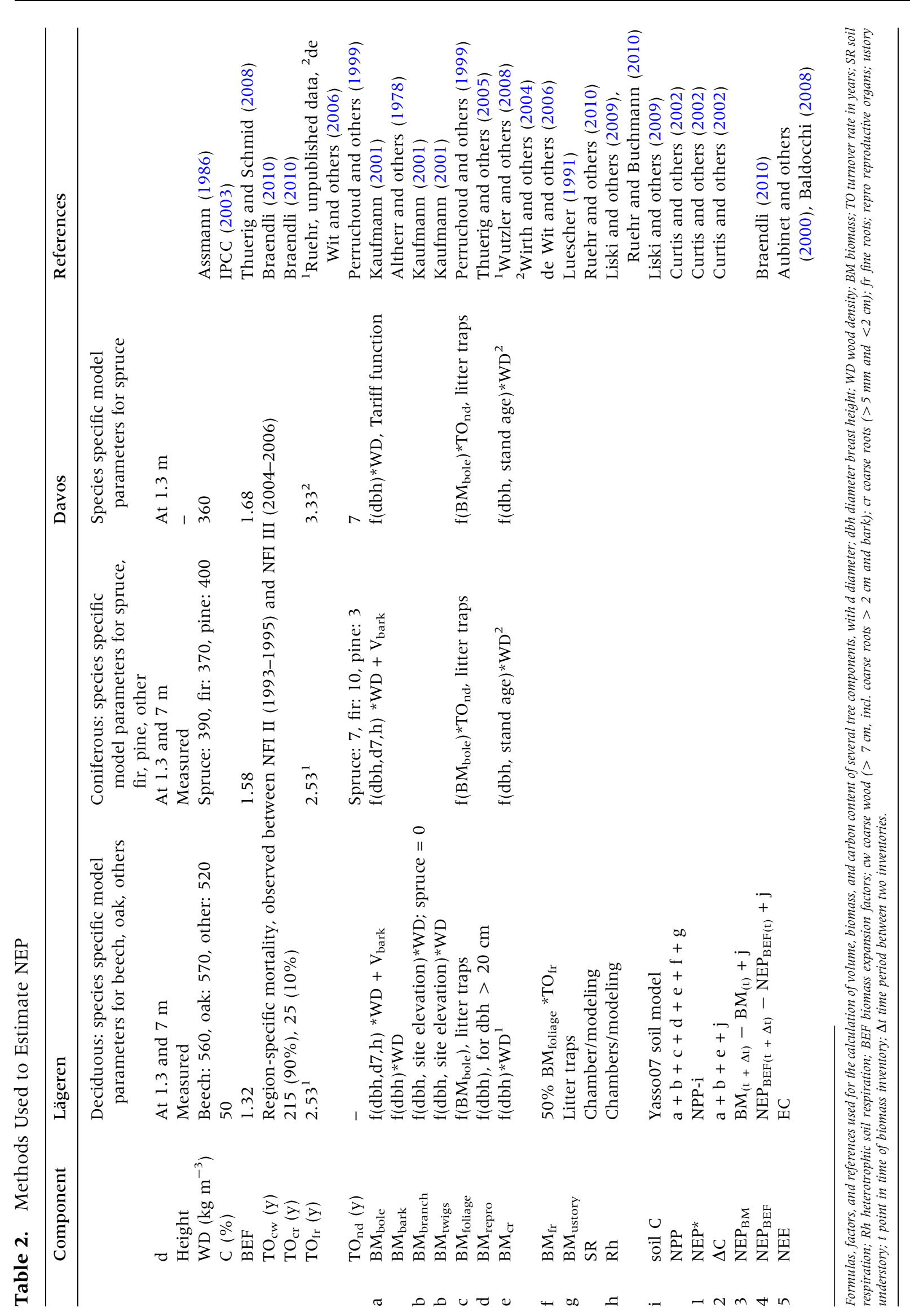


Lägeren site from 2006 to 2009 (Ruehr and others 2010), and at the Davos site from 2008 to 2009 (for details see Table 3). Because the Lägeren study site is rather heterogeneous, 16 plots were established, accounting for the two main soil types and associated vegetation characteristics. At the Davos study site, which is quite homogeneous, four plots were established in the EC footprint area in 2008 and one additional plot was added in 2009 $\left(=S R_{\text {manual }}\right)$. In addition, each site was equipped with an automated SR chamber $\left(=S R_{\text {automated }}\right)$. Details about experimental set-up, measurement routine and partitioning of root and microbial respiration flux at the Lägeren site are described in Ruehr and others (2010) and Ruehr and Buchmann (2010). At the Davos forest, respiration measurements were performed accordingly. Because root density and stone content were much higher at Davos than at Lägeren, careful soil removal was impossible and a slightly different root exclusion approach was applied for the partitioning of the soil respiration flux. Within $3 \mathrm{~m}$ of the SR collars, root exclusions were installed in May 2009 as follows. Around each $50 \times 50-\mathrm{cm}$ root exclusion treatment area trenches were dug down to $30 \mathrm{~cm}$ depth, thereby cutting all roots. Then, the sides of the root exclusion plots were covered by a plastic foil to prevent roots from growing back into the treatment plot from outside. At the same time, a PVC collar was inserted in the center of each root exclusion treatment plot for later measurement of microbial respiration.

To estimate seasonal and annual soil $\mathrm{CO}_{2}$ efflux, we used temperature response functions (Lloyd and Taylor 1994), as described by Ruehr and others (2010), and Ruehr and Buchmann (2010). At Davos, each year was divided into a summer season starting after snow melt (15 May-14 Nov) with valid SR data, and a winter season when the soils were covered with snow (1 Jan-14 May and 15 Nov-31 Dec), during which SR measurements with chambers were impossible. Originally we used temperature dependencies of SR, established during the growing season, to estimate the winter season SR. However, this resulted in unrealistically high fluxes of $0.98 \pm 0.40 \mu \mathrm{mol} \mathrm{CO} \mathrm{CO}_{2} \mathrm{~m}^{-2} \mathrm{~s}^{-1}$ on average (compare with TER on average $1.70 \pm 0.03 \mu \mathrm{mol}$ $\left.\mathrm{CO}_{2} \mathrm{~m}^{-2} \mathrm{~s}^{-1}\right)$. Therefore, SR rates during the winter season were set to $0.5 \mu \mathrm{mol} \mathrm{CO}_{2} \mathrm{~m}^{-2} \mathrm{~s}^{-1}$, which results in $10 \%$ contribution of winter soil respiration to annual soil respiration, according to studies of soil respiration fluxes under a closed snow-cover in coniferous mountain forests (see McDowell and others 2000; Monson and others 2006; Schindlbacher and others 2007; Liptzin and others 2009).

\section{Soil C Sequestration}

To estimate annual soil C storage, we used the Yasso07 soil C model (Vers. 1.0.2) (Liski and others

Table 3. Instrumentation Specifications and Measurement Details for the EC, Soil Respiration, Forest Inventory, and Meteorological Measurements at the Lägeren and Davos Site

\begin{tabular}{|c|c|c|}
\hline & Lägeren & Davos \\
\hline \multicolumn{3}{|l|}{ Biomass inventory } \\
\hline Date of inventory & 2005,2009 & $1988,2006,2011$ \\
\hline Size (ha) & 1.48 & 0.66 \\
\hline Measured parameters & dbh, diameter at $h=7 \mathrm{~m}\left(\mathrm{D}_{7}\right)$, tree height & dbh, tree height \\
\hline Soil respiration & (Ruehr and others 2010) & \\
\hline $\mathrm{SR}_{\text {manual }}$ IRGA/repetitions/time period & $\mathrm{Li}-8100 / n=17 / 2006-2009$ & $\mathrm{Li}-8100 / n=5 / 2008-2009$ \\
\hline $\mathrm{SR}_{\text {aut }}:$ IRGA/repetitions/time period & $\mathrm{Li}-8100 / n=1 / 2006-2009$ & $\mathrm{Li}-8100 / n=1 / 2008-2009$ \\
\hline EC measurements & (Etzold and others 2010) & (Zweifel and others 2010) \\
\hline Time period & 2005-2009 & 1997-2009 \\
\hline Sonic anemometer & Gill solent HS & $\begin{array}{l}\text { Gill solent R2 (1997-2006) } \\
\text { Gill solent R3-50 (2006-2009) }\end{array}$ \\
\hline IRGA & LI-7500 & $\begin{array}{l}\text { Li-6262 } \\
\text { Li } 7500(2005-2005)\end{array}$ \\
\hline Height (m)/height above canopy (m) & $47 / 15$ & $35 / 10$ \\
\hline Data coverage: day/night (\%) & $62 / 24$ & $84 / 61$ \\
\hline Vertical $\mathrm{CO}_{2}$ profile & Li-7000 & Li-6262 (2005-2009) \\
\hline \multicolumn{3}{|l|}{ Meteorological data } \\
\hline Air temperature & Rotronic MP101 A & Rotronic MP400 A \\
\hline Precipitation & MeteoSwiss/NABEL & MeteoSwiss/NABEL \\
\hline Net radiation & Kipp and Zonen CNR I & Kipp and Zonen CNRI \\
\hline
\end{tabular}


2009; Tuomi and others 2009). Yasso07 simulates the stocks of soil organic $\mathrm{C}$, net annual changes in these stocks, and soil microbial respiration. The model only requires basic information on weather, litter quantity and quality (chemical composition). The underlying assumption of Yasso07 is that decomposition depends on litter input type (nonwoody litter and woody litter), their chemical composition (that is, waxes, sugars, cellulose, lignin) and on annual weather conditions (air temperature, temperature amplitude and precipitation). Decomposition of woody litter additionally depends on the size of the litter (for example, coarse woody litter, fine woody litter). The effects of annual weather conditions are modeled by adjusting the decomposition rates of the compartments according to their physical and chemical properties to air temperature and precipitation.

To derive woody litter estimates for the soil C model, we multiplied the woody biomass with specific lifespan estimates as given in Table 2. Litter data were linearly interpolated between forest inventory years. Outside the period covered by inventories, the same rate of change was assumed as could be determined from the closest period with data. The chemical composition of leaves, needles, fine roots and understory litter were derived from Heim and Frey (2004). The chemical compositions of coarse woody litter (average of the chemical composition of stem wood from several tree species) resulted from values given in Liski and others (2009). The chemical composition of fine woody litter was estimated from measurements by Vavrova and others (2009).

We simulated changes in the soil C stock at Lägeren over a 10-year period (2000-2009) and at Davos over a 24-year period (1986-2011) using annual litter input with two diameter classes for wood $(2 \mathrm{~cm}$ for fine wood, that is, twigs, bark, reproductive organs, coarse roots $<2 \mathrm{~cm}$; and $10 \mathrm{~cm}$ for coarse wood, that is bole wood and coarse roots $>10 \mathrm{~cm}$ ) and annual air temperature, the amplitude of air temperature and precipitation data. The initial soil C stocks were assumed to be in steady state, calculated from the litter input at the beginning and the mean annual temperature and precipitation over the past 20 years prior to the simulation start. For both study sites, the modeled initial soil C stocks (Lägeren: $9.6 \mathrm{~kg} \mathrm{~m}^{-2}$, Davos: $9.7 \mathrm{~kg} \mathrm{~m}^{-2}$ ) were well within the range of measured soil C stocks (Table 1). The annual soil sequestration rate of both forests was then calcu-

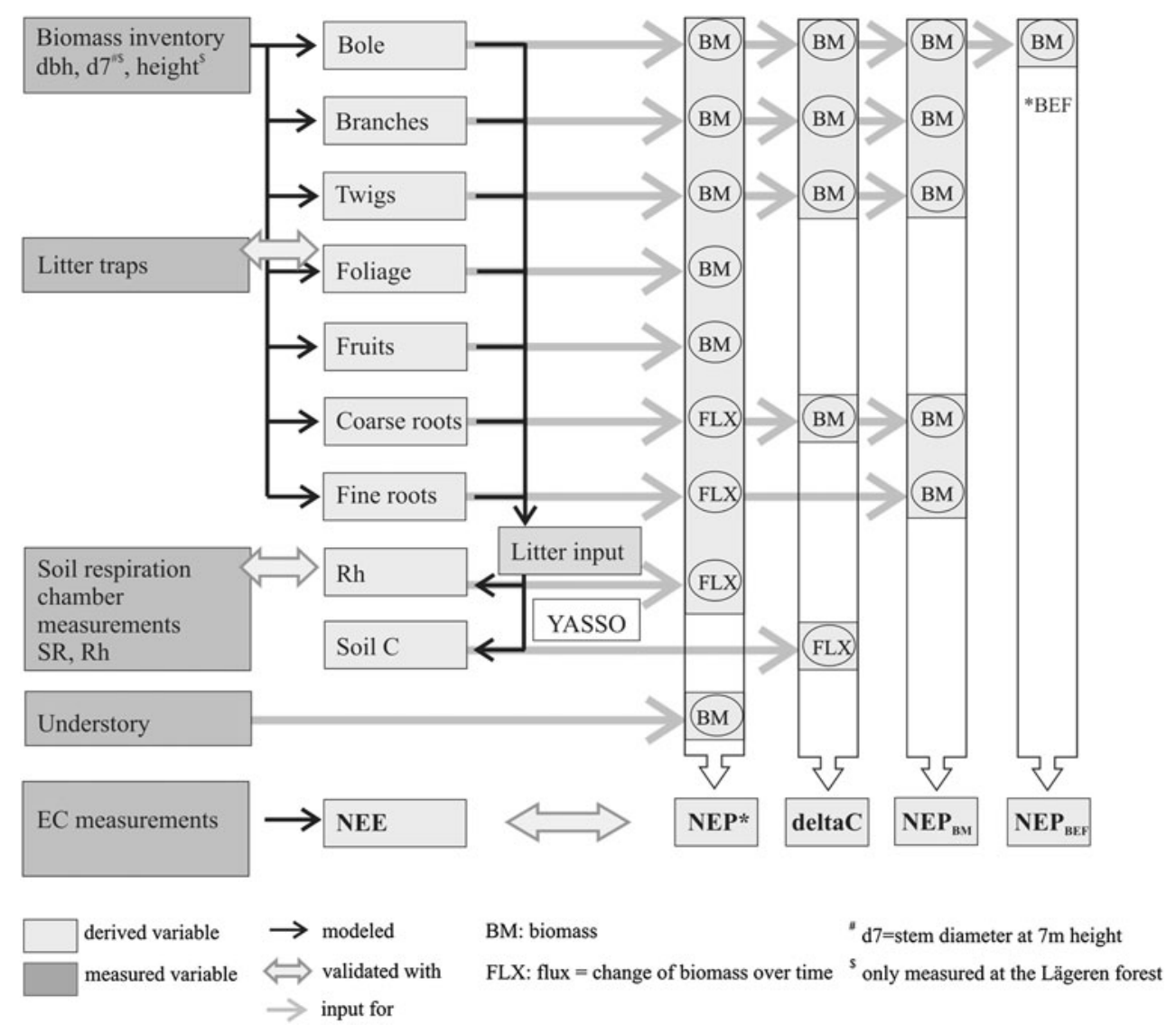

Figure 1. Flowchart for calculation of the different NEP estimates and NEE. 
lated as the average of the years covered by the forest inventory.

\section{Net Ecosystem Production (NEP)}

NEP was calculated by four different approaches: $\mathrm{NEP}^{*}, \Delta \mathrm{C}, \mathrm{NEP}_{\mathrm{BM}}$, and $\mathrm{NEP}_{\mathrm{BEF}}$ (Figure 1; Table 2).

\section{(1) $\mathrm{NEP}^{*}$}

$\mathrm{NEP}^{*}$ was assessed by estimating the change of stored $\mathrm{C}$ in the biomass over time. This included the net gain of $\mathrm{C}$ by tree growth and understory production minus the loss by heterotrophic respiration (Table 2).

\section{(2) $\Delta \mathrm{C}$}

Assuming the loss from herbivory to be small and the annual increment of foliage and fine roots to be zero, NEP can also be expressed as the annual increment in the woody biomass and soil C storage, and is named $\Delta C$ (Curtis and others 2002).

(3) $\mathrm{NEP}_{\mathrm{BM}}$

$\mathrm{NEP}_{\mathrm{BM}}$ is the change of aboveground and belowground woody and non-woody $\mathrm{C}$ pools over time (Table 2).

(4) $\mathrm{NEP}_{\mathrm{BEF}}$

Tree biomass is derived from stem biomass, multiplied with biomass expansion factors (BEF). BEF extrapolate from the wood stock biomass either to aboveground or total biomass, and are region and species specific. According to the Swiss NFI, we used $\mathrm{BEF}$ for coniferous and broad-leafed trees, that were adapted to specific regions and altitudinal ranges in Switzerland (Table 2). $\mathrm{NEP}_{\mathrm{BEF}}$ was not used to validate our EC measurements as they are regarded as uncertain themselves, but were included into the comparison as they are applied widely.

\section{Uncertainty of NEP Estimates}

The best estimates of uncertainty intervals for $\mathrm{C}$ pools and flux components were obtained from the literature and from comparison of modeled with measured data when available. Uncertainty estimates of $\mathrm{C}$ pool and flux calculations included uncertainties originating from parameter estimates of the applied models, and the uncertainties of the underlying model assumptions (such as the fine root turnover). Uncertainties for the input data (stem volume) and model parameters for branches, coarse and fine roots were set as compiled from the literature by de Wit and others (2006). This resulted in high uncertainty estimates for the carbon pools, but reduced to narrow uncertainty intervals for the estimates of the changes in biomass (de Wit and others 2006).

The standard error of the bole volume function used for the Lägeren site is given as $0.3 \%$, and for the tariff function used for the Davos site as $7.8 \%$ (Kaufmann 2001). Uncertainties of the annual soil C stock, of the change in the soil C stock and of microbial respiration rates originating from the parameter estimates of the soil C model Yasso07 were estimated from Monte-Carlo simulations by sampling 1,000 times the parameter estimates. Errors are presented as the $95 \%$ confidence interval. Foliage uncertainty was assessed by comparing modeled versus measured litter data at the Lägeren site $(4.9 \%$ difference). The uncertainty of understory biomass was calculated as the SD of the available measurements (Luescher 1991).

The overall uncertainty of the NEP estimates results from the combined uncertainty of all included components by the error accumulation principle.

$$
\delta_{\mathrm{NEP}}=\sqrt{\sum_{1}^{n} \delta_{\mathrm{c}}^{2}}
$$

with $n=$ number of forest components included in NEP estimate and $\mathrm{c}=$ forest component.

\section{Radial Stem Increment}

In addition to the NEP estimates derived from allometric relationships we calculated the annual C uptake by radial stem growth. At Davos, stem radius changes $(\mathrm{DR}=$ Difference in Radius over time) of Norway spruce trees were measured with twelve automated point dendrometers (ZB06, Zweifel Consulting, Hombrechtikon, Switzerland) every $10 \mathrm{~s}$ and averaged every $30 \mathrm{~min}$ (for details see Zweifel and others 2010). At the Lägeren, two automated point dendrometers (Agricultural Electronics Corporation, Tucson, AZ, USA) per tree were mounted on the north and south sides of the stems of four beeches, and two ash, fir and spruce trees. Stem radius changes were measured every $5 \mathrm{~min}$ and were averaged every $30 \mathrm{~min}$. Each measurement was corrected for the effect of thermal expansion of the dendrometer using laboratory-derived temperature sensitivity using a linear temperature response function.

The annual $\mathrm{C}$ uptake determined by radial stem growth $\left(=\mathrm{DR}_{\mathrm{C}}\right)$ was calculated as follows. Stem volume increment was derived from DR rates by applying stem volume functions (Zweifel and Haesler 2001, using a correction factor of 1). The rate of change in stem volume was converted into 
the $\mathrm{DR}_{\mathrm{C}}$ by multiplication with wood density values and then spatially extrapolated using tree species density measurements. Stem wood and phloem were assumed to contribute 85 and $15 \%$, respectively, to the total annual stem volume increment (Zweifel and Eilmann, personal communication).

\section{Micrometeorological Measurements}

Continuous measurements of half-hourly turbulent $\mathrm{CO}_{2}$ exchange were made with $\mathrm{EC}$ systems on the uppermost platform of the flux towers. Instrumentation specifications and measurement settings for each site are given in Table 3. Raw fluxes of $\mathrm{CO}_{2}$ and water vapor were collected digitally at $20 \mathrm{~Hz}$ and post-processed by the inhouse software ethflux (compare Mauder and others 2008). As the planar fit method was identified as not suitable at least for the Lägeren site (Goeckede and others 2008), a 2-dimensional coordinate rotation for the wind vector for each averaging period was done: rotation of the coordinate system into the mean streamline and alignment of the vertical wind vector, so that $\bar{w}=0$. Flux measurements were corrected for high-frequency damping losses of the instruments (Eugster and Senn 1995), and openpath infra-red gas analyzer (IRGA) measurements were additionally corrected for water vapor transfer effects (Webb and others 1980) and sensor selfheating (Burba and others 2008; Jaervi and others 2009). The resulting $\mathrm{CO}_{2}$ flux data $\left(F_{N}\right)$ were screened for quality by instrumental failure, snow, dew, or ice on the sensor, high window dirtiness of the IRGA sensor $(>60 \%)$, for out of range fluxes $\left(-50 \mu \mathrm{mol} \mathrm{m}{ }^{-2} \mathrm{~s}^{-1}>F_{N}<50 \mu \mathrm{mol} \mathrm{m}{ }^{-2} \mathrm{~s}^{-1}\right)$, for $\overline{u^{\prime} w^{\prime}}<0 \mathrm{~m} \mathrm{~s}^{-1}$ (Eugster and others 2003), and for low friction velocity: Lägeren: $u^{*}<0.3 \mathrm{~m} \mathrm{~s}^{-1}$ (Etzold and others 2010), Davos: $u^{*}<0.2 \mathrm{~m} \mathrm{~s}^{-1}$ (compare Zweifel and others 2010). We removed negative night-time data and a corresponding amount of positive night-time data by a trimmed mean approach. Advection measurements at both sites indicated that horizontal advection is present at the Lägeren site, but is captured mostly by a $u^{*}$ filter of $0.3 \mathrm{~m} \mathrm{~s}^{-1}$ (Etzold and others 2010). At Davos, the horizontal advection term was negligible as horizontal wind speed is very low. The $u^{*}-$ threshold of $0.2 \mathrm{~m} \mathrm{~s}^{-1}$ accounted for most of the observed negative nocturnal fluxes, which were attributed to the occurrence of advection.

For calculating annual C budgets, a complete data set is necessary and gaps of missing flux data have to be replaced by modeled data. Small gaps of $\mathrm{CO}_{2}$ flux data $(<2 \mathrm{~h})$ were replaced by linear interpolation. Larger day-time gaps were modeled with light response curves, by relating day-time $F_{N}$ to photosynthetic photon flux density (PPFD) within a moving window of variable size depending on available data points $(n=50)$ using a logistic sigmoid function according to Moffat (2010). Larger nighttime gaps were modeled by temperature response functions, relating night-time $F_{N}$ within a moving window of variable size depending on available data points $(n=50)$ to air temperature (Lloyd and Taylor 1994). For periods where no temperature response function could be established, as was the case for example during winter periods with temperatures below $0^{\circ} \mathrm{C}$, we used a running mean approach. At the Lägeren site we observed high positive and negative fluxes $\left( \pm 15 \mu \mathrm{mol} \mathrm{m} \mathrm{m}^{-2} \mathrm{~s}^{-1}\right)$ during the dormant period at very low temperatures, which we interpreted as non-biotic fluxes, possibly related to weathering or dissolving processes of calcareous soil substances (compare Kowalski and others 2008; Serrano-Ortiz and others 2010) and the occurrence of fog and a stable inversion layer. We kept these data in the data set but excluded them from the gapfilling algorithm, which was used to establish light and temperature response functions. Ecosystem respiration (TER) was derived from the temperature dependencies established during the night (Reichstein and others 2005) and extrapolated to day-time conditions within a moving window of two weeks length. Gross primary production (GPP) was defined as GPP $=$ NEE - TER.

\section{Uncertainty of NEE}

Uncertainty of NEE was computed as the random uncertainty of EC flux measurements and the uncertainty introduced by gap-filling by combining both terms in quadrature. The random uncertainty of EC measurements was calculated by the successive day approach described in Hollinger and Richardson (2005). We found the probability distribution of the random flux errors best described by the double-exponential distribution as in Hollinger and Richardson (2005). The resulting random error was on average $9.4 \%$ for the Davos data (range $3-17 \%$ ) and on average $2.8 \%$ (range $1.7-3.4 \%$ ) for the Lägeren data.

To assess the error caused by gap-filling we randomly produced $20 \%$ artificial gaps in each yearly time period and compared the resulted gap-filled data with the original data. We repeated this procedure 50 times and calculated the gap-filling uncertainty from the model residuals according to Aurela and others (2002). For Davos, the mean uncertainties in relation to the mean measured flux were $2.2 \%$ for day-time gaps and $9 \%$ for night-time 


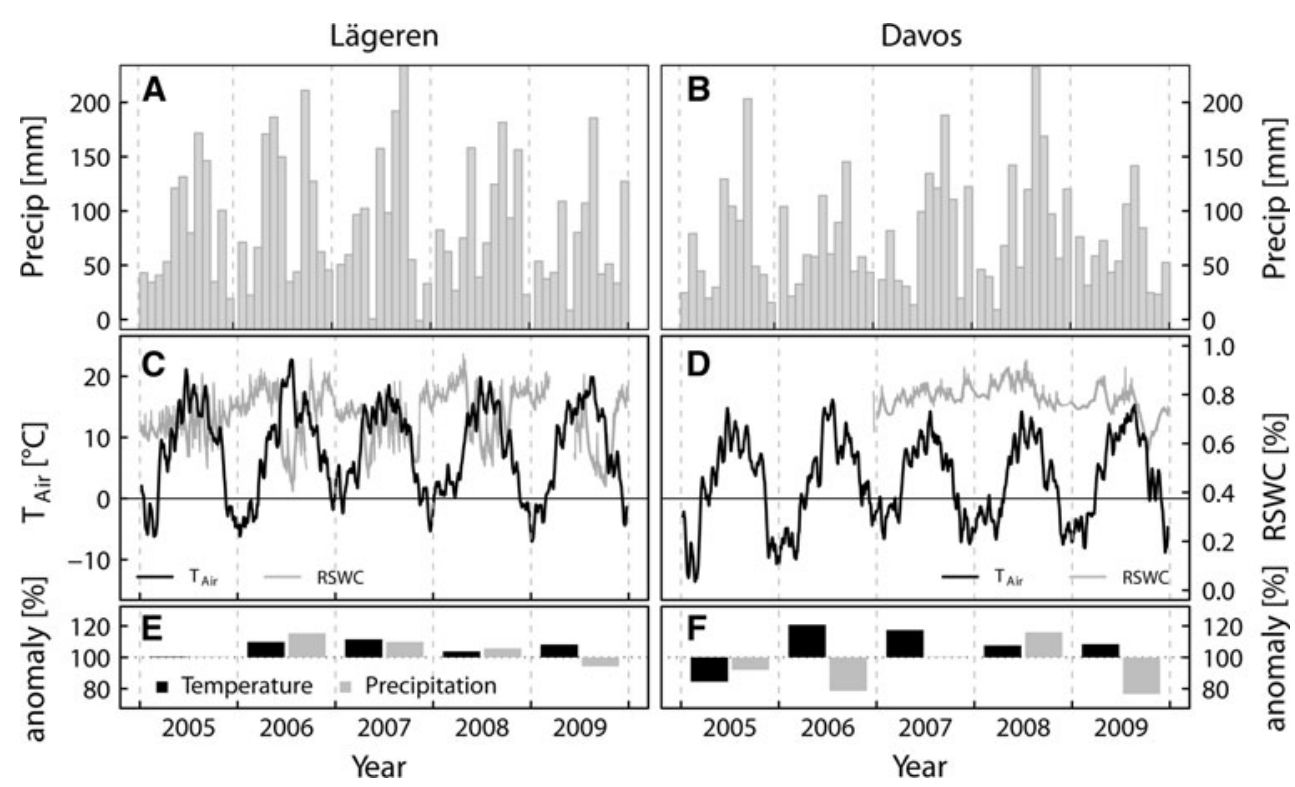

Figure 2. Climatic conditions at the Lägeren (A, C, E) and the Davos site $(\mathbf{B}, \mathbf{D}, \mathbf{F})$ during the observation period from 2005 to 2009: Monthly precipitation sums (A, B), monthly mean air temperature and relative soil moisture content (RSWC) (C, D), and percentage anomalies of mean annual temperature (black bars) and mean annual precipitation sum (gray bars) related to the 20-year mean values (E, F).

gaps, which amounted on a yearly basis on average to $27 \%$ (range $11-50 \%$ ) and $\pm 28 \mathrm{~g} \mathrm{C} \mathrm{m}^{-2} \mathrm{y}^{-1}$ depending on the gap-frequency and flux magnitude. For the Lägeren, the mean uncertainties were $0.92 \%$ for day-time gaps and $1.5 \%$ for night-time gaps. Applied to all gap-filled periods, these uncertainties resulted in 6\% (range $4.1-7.8 \%$ ) and $\pm 26 \mathrm{~g} \mathrm{C} \mathrm{m}^{-2} \mathrm{y}^{-1}$ per year. For the annual sums of TER and GPP we applied a maximum error of $\pm 25 \%$ (Desai and others 2008).

\section{Meteorological Data}

Standard meteorological variables, such as air temperature and radiation components were measured on the uppermost platform of the flux tower (Table 3). Additional meteorological data were obtained from the National Air Pollution Monitoring Network NABEL (precipitation), the Swiss Federal Office of Meteorology and Climatology MeteoSwiss (long-term meteorological data).

\section{RESUltS}

The Lägeren and Davos forests are two contrasting mountain forest types, representative for their altitudinal range in Switzerland. The following differences between the Lägeren and Davos forests are considered the most important: (1) much cooler climate at Davos site compared to Lägeren, (2) high species diversity at Lägeren compared to the predominance of spruce trees at Davos, and (3) the age of the trees. At Davos most of the trees are much older than those at the Lägeren site (see Table 1).

\section{Climate Conditions}

The mean daily course of temperatures for the Davos and the Lägeren sites were nearly identical but mean monthly temperature values at Lägeren were almost constantly $5^{\circ} \mathrm{C}$ higher than at Davos (Figure 2, linear regression of mean monthly temperatures: $\left.R^{2}=0.92, P<0.01\right)$. In contrast, annual sums as well as seasonal patterns of precipitation differed between sites (linear regression of monthly precipitation sums: $R^{2}=0.32, P<0.01$ ), with a more distinct seasonality of precipitation at the Davos forest (Figure 2A, B). For both sites mean annual temperatures in the years 2006-2009 were above the long-term (20 years: 1989-2009) average, whereas the year 2005 was comparably cool, especially at the Davos site. Although the long-term annual precipitation sums were in the same range (Table 1), annual precipitation patterns differed. At the Lägeren site, the observation period was wetter compared to the long-term average. At the Davos forest, only the year 2008 was wetter than the longterm average, the years 2006 and 2009 received less than $80 \%$ of the long-term mean annual precipitation. Whereas the Lägeren forest received the largest amount of precipitation in 2006 and only the summer months were dry, the Davos forest experienced one of the driest and also warmest years within the study period.

\section{The C Balance of the Two Forest Sites}

EC measurements, as well as biometric estimates indicate that both sites were significant $\mathrm{C}$ sinks (Figure 3; Tables 4, 5). Hereby, annual sums of 


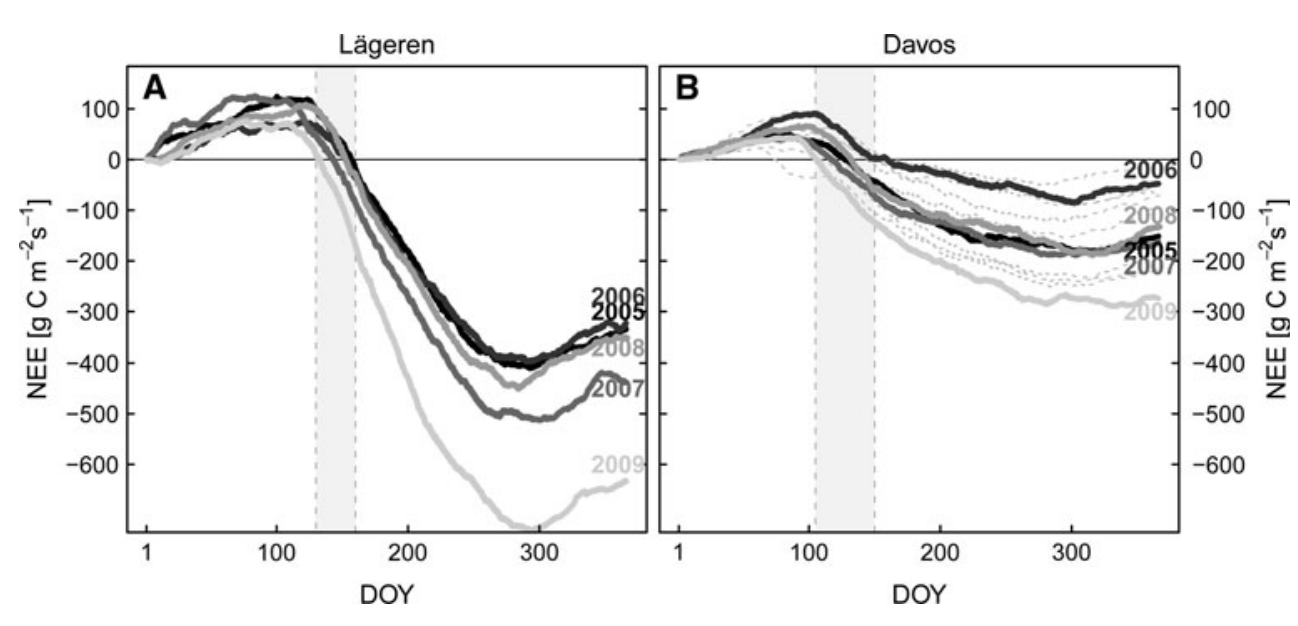

Figure 3. Cumulative NEE for $\mathbf{A}$ the Lägeren and $\mathbf{B}$ the Davos forest for the years 2005-2009. For the Davos site, NEE of previous measured years (1997-2004) is shown by gray dotted lines. Gray areas indicate the range of $\mathrm{DOY}_{0}$, the compensation point when the net $\mathrm{C}$ uptake balances the net $\mathrm{C}$ losses that accumulated since the beginning of the calendar year.

Table 4. Mean Annual C Budgets (NEE, GPP, TER), Derived from EC, Soil SR and Rh, Derived from Soil Respiration Chamber Measurements, Soil C Derived from Soil C Modeling (Yasso07), and Carbon Uptake by Radial Stem Increment $\left(D_{C}\right)$ for the Lägeren and the Davos Forest

\begin{tabular}{|c|c|c|c|c|}
\hline & Lägeren & Timespan & Davos & Timespan \\
\hline $\operatorname{NEE}\left(\mathrm{Mg} C \mathrm{ha}^{-1} \mathrm{y}^{-1}\right)$ & $-4.15( \pm 0.56)$ & 2005-2009 & $-1.53( \pm 0.54)$ & 2005-2009 \\
\hline GPP $\left(\mathrm{Mg} \mathrm{C} \mathrm{ha-1} \mathrm{y}^{-1}\right)$ & $-18.30( \pm 4.48)$ & 2005-2009 & $-10.38( \pm 2.54)$ & 2005-2009 \\
\hline $\operatorname{TER}\left(\mathrm{MgC} \mathrm{ha} \mathrm{h}^{-1} \mathrm{y}^{-1}\right)$ & $+13.83( \pm 3.38)$ & 2005-2009 & $+8.85( \pm 2.16)$ & 2005-2009 \\
\hline SR $\left(\mathrm{Mg} \mathrm{C} \mathrm{ha} \mathrm{h}^{-1} \mathrm{y}^{-1}\right)$ & $+8.90( \pm 0.46)$ & 2006-2009 & $+9.18( \pm 0.83)$ & $2008-2009$ \\
\hline $\mathrm{Rh}\left(\mathrm{Mg} \mathrm{C} \mathrm{ha} \mathrm{C}^{-1} \mathrm{y}^{-1}\right)$ & $+5.07( \pm 0.48)$ & 2007,2008 & $+4.23( \pm 0.07)$ & 2008-2009 \\
\hline Soil C $\left(\mathrm{Mg} \mathrm{C} \mathrm{ha}^{-1} \mathrm{y}^{-1}\right)$ & $-0.23( \pm 0.10)$ & 2005-2009 & $-0.50( \pm 0.07)$ & 2005-2009 \\
\hline $\mathrm{DR}_{\mathrm{C}}\left(\mathrm{MgC} \mathrm{ha}^{-1} \mathrm{y}^{-1}\right)$ & $-3.75( \pm 1.13)$ & $2006-2007$ & $-1.15( \pm 0.35)$ & 2006-2007 \\
\hline
\end{tabular}

NPP, NEP, NEE, GPP, TER, Rh, as well as $\mathrm{DR}_{\mathrm{C}}$ were higher at Lägeren compared to Davos during the years 2005-2009 (Table 4). Annual soil respiration was, however, of the same order of magnitude at both sites and soil $\mathrm{C}$ sequestration rates were higher at the Davos site.

The overall aboveground $\mathrm{C}$ pool (derived from allometric estimates) of the Lägeren forest (178.2 $\left.\mathrm{Mg} \mathrm{C} \mathrm{ha}{ }^{-1}\right)$ was larger than at Davos (105.3 $\mathrm{Mg} \mathrm{C} \mathrm{ha}{ }^{-1}$ ), but with reversed results in the belowground pools (Table 5). As a corollary, the aboveground $\mathrm{C}$ turnover at Lägeren $(6.11 \mathrm{Mg} \mathrm{C}$ $\mathrm{ha}^{-1} \mathrm{y}^{-1}$ ) was more than double the rate observed at Davos (2.85-3.07 Mg C ha-1 $\left.\mathrm{y}^{-1}\right)$, whereas the belowground $\mathrm{C}$ turnover was higher at Davos. A higher NPP of the Lägeren forest, but an almost identical respiration flux at the Lägeren and Davos sites then led to higher net $\mathrm{C}$ uptake capacity at Lägeren compared to Davos. We did not expect to find similar annual SR rates at both study sites as the Davos forest is subject to a much cooler climate than the Lägeren forest. But this finding can be explained by the higher temperature sensitivity of SR at the Davos forest: $S R$ rates at Davos ( $\mathrm{SR}_{\text {automated }}$ : $\left.R_{\text {ref }}=4.19, \mathrm{SR}_{\text {manual }}: R_{\text {ref }}=4.38\right)$ doubled those at the Lägeren forest $\left(\mathrm{SR}_{\text {automated }}: R_{\mathrm{ref}}=1.91\right.$, $\mathrm{SR}_{\text {manual }}: R_{\mathrm{ref}}=2.22$ ) for a temperature range between 5 and $10^{\circ} \mathrm{C}$ for 2008 and 2009 (Figure 4).

\section{Biometric versus Meteorological Estimates of Forests' C Storage}

At both sites, NEE derived from EC measurements agreed with NEP estimates (Table 5). In general, $\mathrm{NEP}^{*}$ was the lowest of all NEP estimates at both sites. At the Lägeren site, $\mathrm{C}$ uptake derived from NEE (4.35 Mg C ha-1 $\mathrm{y}^{-1}$ ) was higher than calculated $\mathrm{NEP}^{*}$ (3.07 Mg C ha ${ }^{-1} \mathrm{y}^{-1}$ ), but was very close to estimates of $\Delta \mathrm{C}\left(4.29 \mathrm{MgC} \mathrm{ha}^{-1} \mathrm{y}^{-1}\right)$ and $\mathrm{NEP}_{\mathrm{BM}}$ (4.34 Mg C ha- $\left.\mathrm{y}^{-1}\right) \cdot \mathrm{NEP}_{\mathrm{BEF}}\left(5.14 \mathrm{Mg} \mathrm{C} \mathrm{ha}^{-1} \mathrm{y}^{-1}\right)$ was higher than all other estimates. At the Davos site, NEP estimates of the two time periods investigated were in the same range (differences: -0.14 to $0.61 \mathrm{MgC} \mathrm{ha} \mathrm{C}^{-1} \mathrm{y}^{-1}$ ). All NEP estimates indicate a slightly higher yearly net uptake during the years 2006-2010, compared to the time period 19882006, except $\mathrm{NEP}_{\mathrm{BEF}}$. NEE measurements were available from 1997 to 2009. For the time period from 1997 to 2006 EC measurements yielded 1.17 $\mathrm{Mg} \mathrm{C} \mathrm{ha}^{-1} \mathrm{y}^{-1}$ carbon uptake, which is lower 


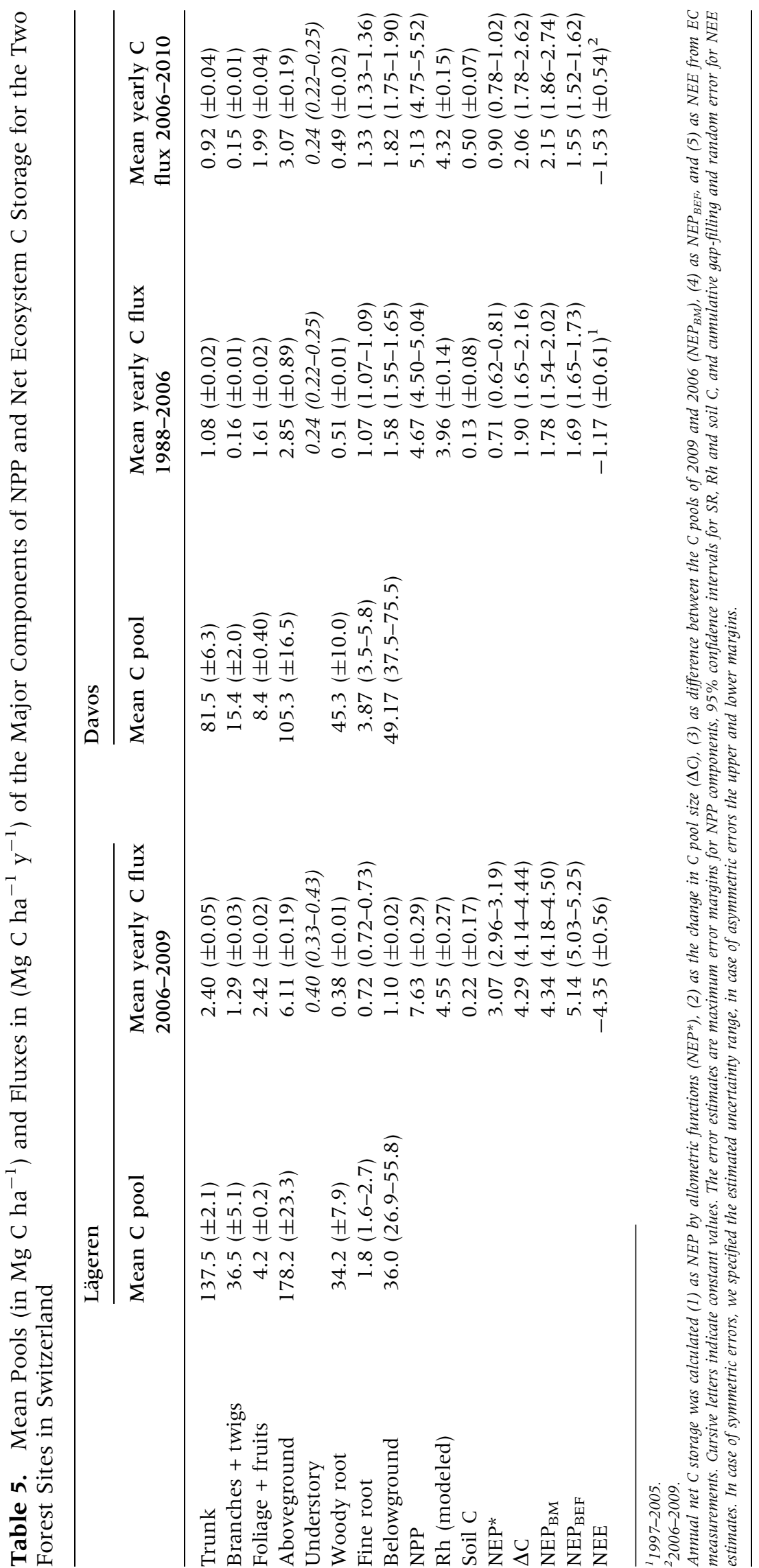




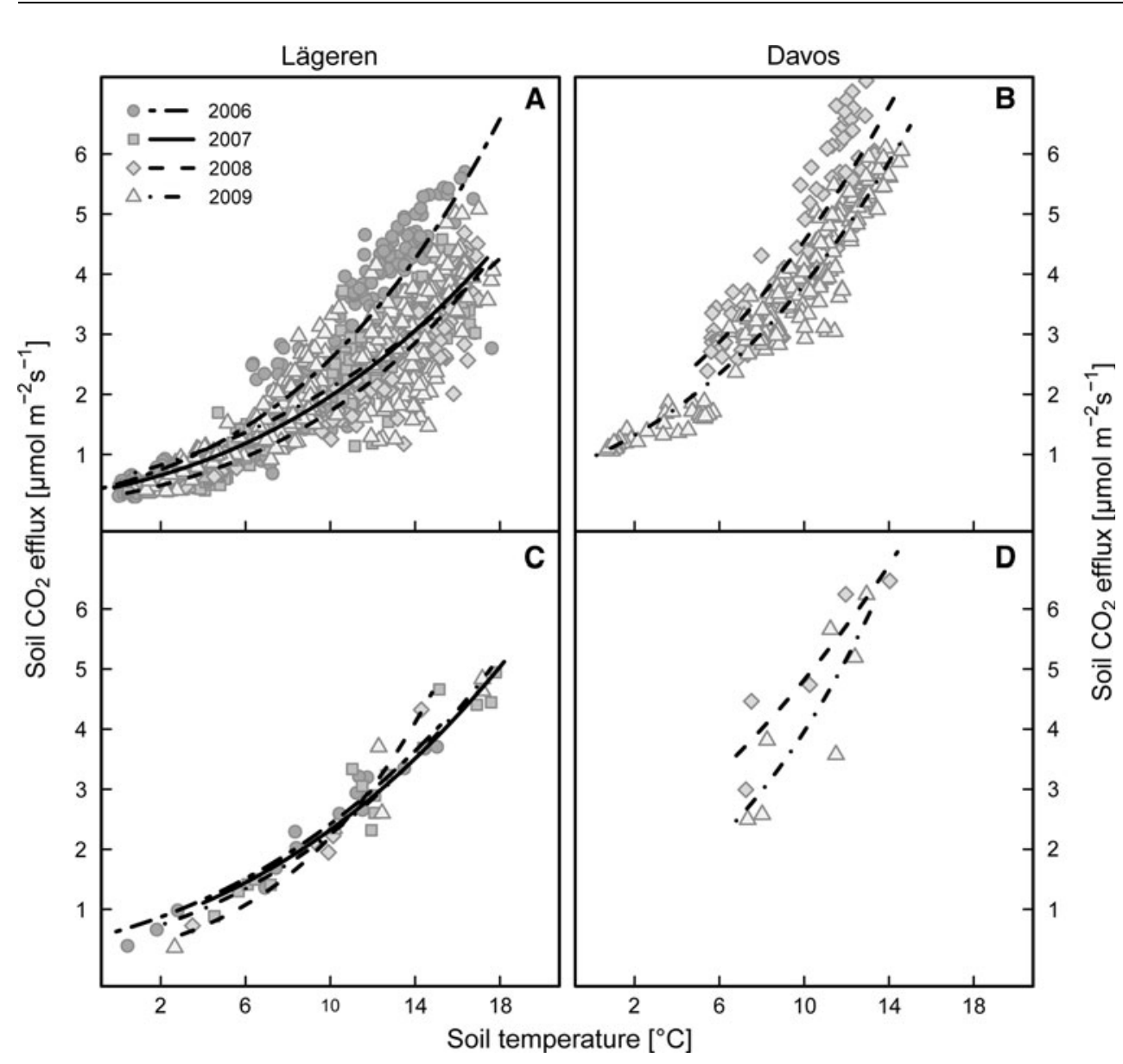

Figure 4. Temperature dependency of soil respiration at the Lägeren (A, C) and Davos (B, D) forests. Shown are daily averages for $S R_{\text {automated }}$ and campaign averages for $S R_{\text {manual, }}$ as well as fitted lines of the Lloyd-Taylor function for each study year. Please note that $S R$ data in 2006 are only given for nonwater-limiting periods (volumetric soil moisture $>15 \%$ ).

than $\Delta \mathrm{C}, \mathrm{NEP}_{\mathrm{BM}}$, and $\mathrm{NEP}_{\mathrm{BEF}}$. Recall that these estimates covered a different time period than the EC measurements and hence may not exactly reflect the same growth conditions. NEE from 2006 to 2009 $\left(-1.53 \mathrm{Mg} \mathrm{C} \mathrm{ha}^{-1} \mathrm{y}^{-1}\right)$ compared well to NEP (0.9-2.15 Mg C ha-1 $\mathrm{y}^{-1}$ ) for the time period from 2006 to 2010 .

\section{Temporal Patterns of C Uptake}

During 2005-2009, NEE of the Lägeren forest ranged from -366 to $-662 \mathrm{~g} \mathrm{C} \mathrm{m}^{-2} \mathrm{y}^{-1}$ (mean: $\left.-415 \mathrm{~g} \mathrm{C} \mathrm{m}^{-2} \mathrm{y}^{-1}\right)$, and in the Davos forest from -47 to $-274 \mathrm{~g} \mathrm{C} \mathrm{m}^{-2} \mathrm{y}^{-1}$ (mean: $-154 \mathrm{~g} \mathrm{C}^{-}$ $\left.\mathrm{m}^{-2} \mathrm{y}^{-1}\right)$. Overall, the inter-annual variability (coefficient of variation, $\mathrm{CoV}$, defined as the variance normalized by the mean) of NEE at the Davos forest was higher than at the Lägeren $\left(\mathrm{CoV}_{\text {Davos }}=\right.$ 0.53; $\left.\mathrm{CoV}_{\text {Lägeren }}=0.31\right)$. Nevertheless, both forests showed similar annual trends of net $\mathrm{CO}_{2}$ uptake with lowest rates for the year 2006, high uptake in 2007, and an extraordinary high net uptake in 2009 (Figure 3). Although the annual sums of NEE from both forests showed similar temporal patterns (lin- ear regression model $\mathrm{NEE}_{\text {Lägeren }}$ against $\mathrm{NEE}_{\text {Davos }}$ : adj. $R^{2}$ of $0.71, P=0.05$ ), monthly sums were only weakly related (adj. $R^{2}=0.48, P<0.01$ ) due to different seasonal patterns: In general, the curvature of cumulated NEE ( $\mathrm{NEE}_{\text {Cum }}$ ) was much flatter at the Davos site compared to the Lägeren site, both during winter and summer (Figure 3). The winter respiration compensation point $\mathrm{DOY}_{0}\left(=\mathrm{NEE}_{\text {Cum }}\right.$ crosses the zero-line) occurred nearly 1 month earlier at the Davos forest (mean: DOY 128) than at the Lägeren (mean: DOY 147). Thus, lagging the Davos data by 1 month, cross correlation analysis revealed a close correlation between monthly sums of both forests $\left(R=0.80\right.$, adj. $\left.R^{2}=0.67, P<0.01\right)$, and net sums integrating over 2 months were also closely related (adj. $R^{2}=0.70, P<0.01$ ).

For both forest sites, DOY $_{0}$ had a high explanatory value for the resulting annual net uptake (Davos: adj. $R^{2}=0.71, P<0.01$ for $1997-2009$ and $R^{2}=0.87, P=0.01$ for 2005-2009; Lägeren: adj. $R^{2}=0.92, P<0.01$, for 2005-2009). The later start of the photosynthetic activity of the Lägeren trees was compensated during summer, when the slope of $\mathrm{NEE}_{\text {Cum }}$ was much steeper at Lägeren 

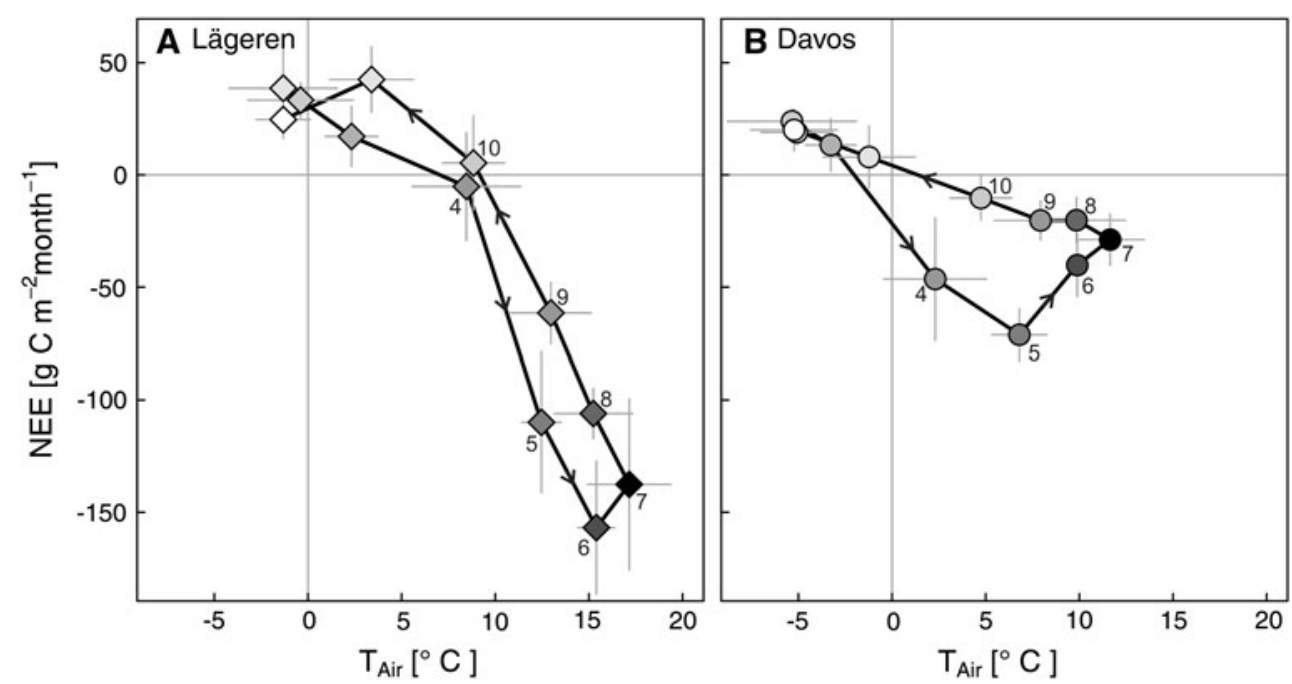

Figure 5. Mean monthly sums of NEE in relation to mean monthly air temperature. Values are means \pm SE. Numbers indicate the respective month of the year. (mean: $-3.7 \mathrm{~g} \mathrm{C} \mathrm{m}^{-2}$ day $^{-1}$ ) compared to Davos (mean: $-1.1 \mathrm{~g} \mathrm{C} \mathrm{m}^{-2} \mathrm{day}^{-1}$ ). In general, at Davos the highest monthly net uptake was already achieved during April/May, whereas at Lägeren the summer months (June/July) yielded the highest monthly net uptake rates (Figure 5). The Davos forest yielded even higher net uptake rates during spring than the Lägeren forest, although spring temperatures were comparably lower. During summer, monthly temperatures still increased at the Davos site, but C uptake decreased. The seasonal course of cumulative net uptake per month in relation to monthly averaged air temperature resulted in a hysteresis plot with a counterclockwise spin (Figure 5). In contrast, the net uptake of the Lägeren forest increased exponentially with increasing temperature and a less pronounced hysteresis.

\section{The Response of Carbon Uptake to Environmental Drivers}

Mean daily NEE of both forests responded differentially to daily temperature, relative soil moisture content (RSWC, Reichstein and others 2005), and PPFD (Figure 6). Net uptake of the Lägeren forest increased with temperature and PPFD, peaking and declining at highest values. Under non-temperature limiting conditions the net flux at the Lägeren showed no relation to soil moisture up to a threshold of $0.8 \%$ RSWC, above which a pronounced increase of mean daily NEE (that is, decrease of net uptake) was observed. The net uptake at the Davos forest showed only a weak response to temperature and PPFD, and remained rather constant above a temperature of $4^{\circ} \mathrm{C}$ and PPFD of $300 \mu \mathrm{mol} \mathrm{m} \mathrm{m}^{-2} \mathrm{~s}^{-1}$. The net uptake increased with increasing soil moisture, especially when winter and spring data with temperatures below $4^{\circ} \mathrm{C}$ were included.

\section{Discussion}

Three main issues were observed in the similarities and differences in the $\mathrm{CO}_{2}$ budgets of the two forest ecosystems: (1) Biometric NEP estimates support NEE measurements by EC, (2) annual trends of NEE are similar among the Lägeren and Davos forest, but with intra-annual differences, and (3) the activity of trees is the main driver of forest $\mathrm{CO}_{2}$ budgets. Based on that, we ask the question of how the latitudinal gradient of European forest $\mathrm{C}$ uptake (Valentini and others 2000) translates to altitudinal differences within a small geographic domain.

\section{Biometric NEP Estimates Support NEE Measurements by EC}

As NEE and NEP are methodologically independent the comparison of both estimates helps to validate the calculations of ecosystem $\mathrm{C}$ budgets, because both approaches are associated with large uncertainties and sources of errors (Curtis and others 2002; Keith and others 2009). Both estimates show that each of the forests is a persistent carbon sink. NEE derived from EC measurements agreed with biometric NEP estimates and deviations between both estimates (Lägeren: 0.5-30\%, Davos: 38$64 \%$ ) lay in the range reported by other studies (for example, Curtis and others 2002; Black and others 2007; Gough and others 2008b; Peichl and others 2010). However, estimates of NEP were already variable themselves, depending on the approach that was applied. Thus, NEP estimates differed by 

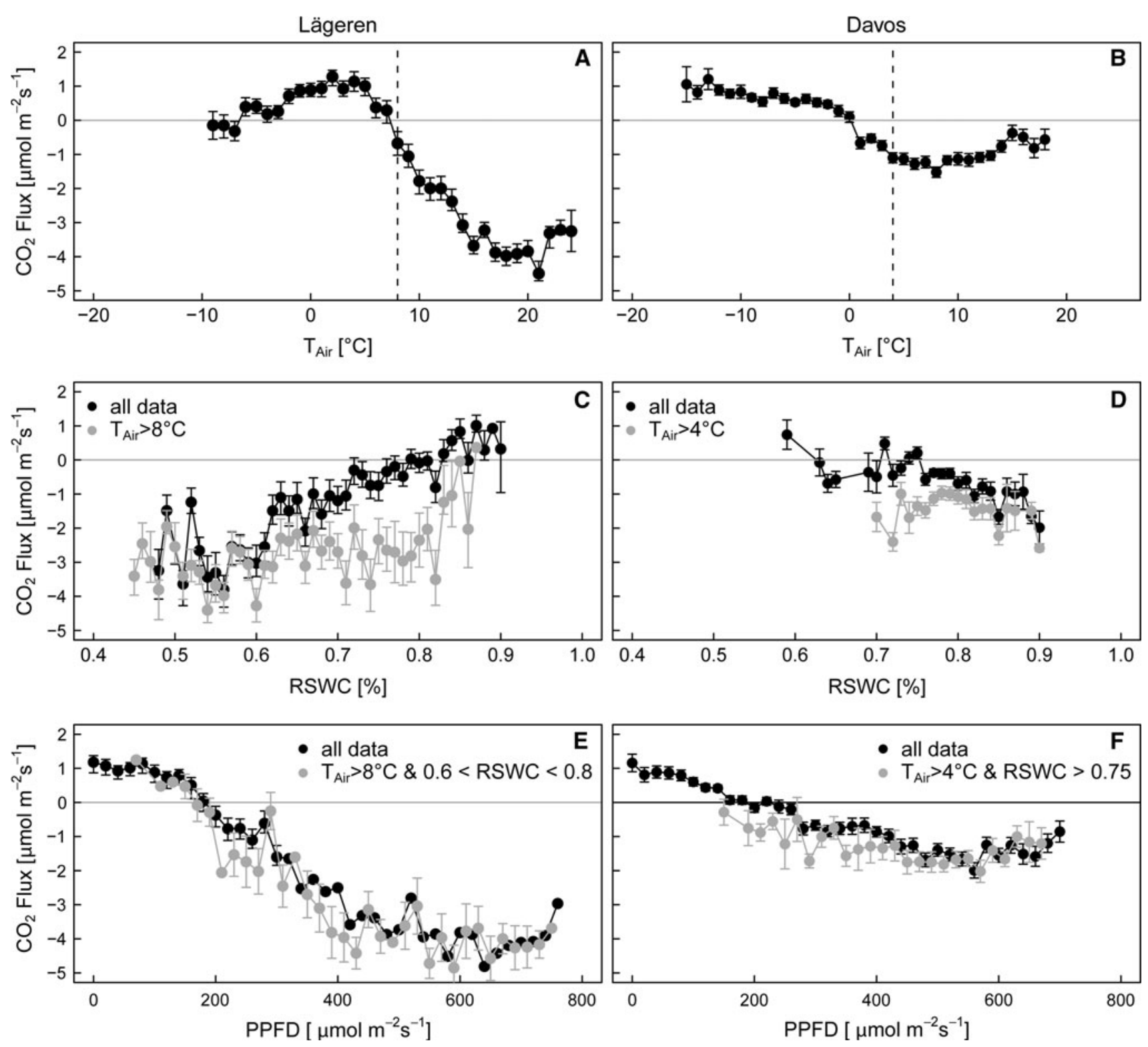

Figure 6. Mean daily $\mathrm{CO}_{2}$ flux in response to mean daily air temperature $\left(T_{\text {Air }}\right)$, bin-averaged in $1^{\circ} \mathrm{C}$ classes $(\mathbf{A}, \mathbf{B})$, in response to relative soil moisture content (RSWC), bin-averaged in $1 \%$ classes $(\mathbf{C}, \mathbf{D})$, and in response to photosynthetic photon flux density (PPFD), bin-averaged in $20 \mu \mathrm{mol} \mathrm{m} \mathrm{m}^{-2} \mathrm{~s}^{-1}$ classes (E, F) for the Lägeren site (A, C, E) and the Davos site $(\mathbf{B}, \mathbf{D}, \mathbf{F})$. Values are means \pm SD for the years 2005-2009.

$127 \mathrm{~g} \mathrm{C} \mathrm{m}^{-2} \mathrm{y}^{-1}( \pm 17 \%$ variability $)$ at the Lägeren site and by $119 \mathrm{~g} \mathrm{C} \mathrm{m}^{-2} \mathrm{y}^{-1}( \pm 39 \%)$ for $1988-2006$ and $125 \mathrm{~g} \mathrm{C} \mathrm{m}^{-2} \mathrm{y}^{-1}( \pm 37 \%)$ for 2006-2010 at the Davos site, but no systematic trend of relationships between NEP and NEE could be observed. The relationships of NEP to NEE are thought to differ with forest type, stand age and species composition (Black and others 2007). Black and others (2007) concluded that NEP calculations based on the mass-balance approach $\left(\Delta \mathrm{C}, \mathrm{NEP}_{\mathrm{BM}}\right.$, and $\mathrm{NEP}_{\mathrm{BEF}}$ ) overestimate NEP due to unaccounted soil decomposition losses. NEP* on the other hand, does not include the $\mathrm{C}$ flux to mycorrhiza, accounting for up to $20 \%$ of host photosynthates (Smith and Read 1997) or the exudation of C from roots to the soil, which can account for $0.5-5 \%$ of the net fixed C (Farrar and others 2003), and therefore likely underestimates NEP. NEP $\mathrm{BEF}_{\mathrm{BE}} \mathrm{com}$ pared well with other NEP estimates at the Davos site, but was significantly higher than all other NEP estimates at the Lägeren site. The ratio of TER/GPP based on the $\mathrm{NEP}_{\mathrm{BEF}}$ estimate for the Lägeren site results in 0.63 . Using a ratio of TER/GPP of 0.74 as a reference for European forest ecosystems (Luyssa- 
ert and others 2009) would indicate that BEF may overestimate the productivity of forests. The simple approximation of NEP from $\mathrm{dbh}$ and only one scaling factor may be especially problematic for such diverse forests as the Lägeren with a huge variety of species, growth forms and spatial differentiations. In addition, BEF do not account for the different turnover times of the individual tree compartments. We conclude that BEF are useful for estimating forest productivity on large scales as for the UNFCCC accounting, when detailed investigations are difficult to carry out. However, they should be applied with great care, especially for broad-leaved or mixed forest stands.

Our comparison of the different approaches clearly identifies crucial areas for future research to further improve our understanding of the forest carbon cycle and to yield reliable estimates of carbon sequestration. The largest uncertainty in our NEP estimates originates from modeling the belowground C dynamics, and especially those of fine roots (compare Curtis and others 2002; Gough and others 2008a; Braendli 2010). Considering these uncertainties the IPCC even recommends using only aboveground BEFs for national inventories (Loewe and others 2000). Furthermore, for mountain forest sites with a long winter season, the cumulative winter fluxes are an important component in budget calculations, but they are difficult to quantify, and hence impose a large uncertainty on $\mathrm{NEP}^{*}$ estimates. Without giving a specific recommendation on the best method for estimating the annual $\mathrm{C}$ storage because no clear trend could be observed, we note that NEP* is the most comprehensive approach, but is associated with the highest uncertainties, mainly introduced by the $\mathrm{C}$ flux calculations. $\triangle \mathrm{C}$ and $\mathrm{NEP}_{\mathrm{BM}}$ are much easier to derive as the non-woody pools are neglected. In our study, they provided robust estimates which compared well with the NEE estimates. Thus, $\Delta \mathrm{C}$ and $\mathrm{NEP}_{\mathrm{BM}}$ appear to be useful and easily applicable tools to get a rough estimate of NEP. However, if the research interest is in the dynamics and contributions of the single forest compartments, then a more sophisticated approach (such as NEP*) is needed.

\section{Temporal Patterns of Net Uptake}

In general, $\mathrm{C}$ budgets of the Davos forest were more variable than those of the Lägeren forest, but both forest sites showed similar trends of annual net uptake during 2005-2009 (Figure 3). This was surprising as the sites were exposed to different climatic conditions between 2005 and 2009 (Figure 2) and responded differentially to environmental variables (Figure 6). Whereas the daily net uptake of the Lägeren was strongly enhanced by temperature and incoming radiation under sufficient moisture conditions, the daily net uptake of the Davos forest was only weakly related to temperature or to PPFD. Thus, we could not detect a temperature limitation of the photosynthetic activity of the Davos trees as was a priori expected for a subalpine site with low annual temperatures. Instead, the net uptake was rather decoupled from seasonal temperature variations, and the highest net uptake rates were observed during April and May under very low temperature conditions, whereas during the warmer summer period comparably low net uptake rates were observed (Figure 5). The temperature uncoupling during the spring snow melt period is also seen in the soil moisture response curve (Figure 6), where net uptake increases with increasing RSWC, which mainly reflects an increasing RSWC during the spring snow melt. The high importance of the spring period and of the availability of snow melt water on annual NEE was already shown for the subalpine forest site Niwot Ridge by Monson and others (2005) and $\mathrm{Hu}$ and others (2010). The temperature decoupling of subalpine ecosystems should be taken into account in ecosystem modeling, in which usually temperature response functions are applied.

The net uptake at the Davos forest started about 1 month earlier compared to the Lägeren forest. Interestingly, monthly sums of NEE of the Lägeren and Davos forest were closely related by lagging the Davos data by 1 month or by integrating NEE over 2 months. Thus, over a longer time period (such as 2 months) the influence of climatic conditions on the forests' net uptake may be overridden by intrinsic forest dynamics (Richardson and others 2007). Despite the highest uptake rates during summer at the Lägeren forest, $\mathrm{DOY}_{0}$ (the ecosystem turns from a source to a sink) also had high predictive power for annual NEE. Thus, the period during which the ratio of GPP and TER is changing, is most critical for the annual NEE, introducing high uncertainties into global change scenarios, as the spring period is expected to undergo large changes, for example, of snow coverage, lengthening of the vegetation period, or increase of snow melt days (Appenzeller and others 2008).

\section{Activity of Trees as Main Determinant for Forest C Budgets}

NPP, NEP, NEE, GPP, TER, as well as $\mathrm{DR}_{\mathrm{C}}$ were strongly increased at Lägeren compared to Davos, whereas Rh was only slightly larger (Tables 4 and 5). 
Thus, differences in the $\mathrm{C}$ balance of the two forests, namely the higher productivity of the Lägeren forest, can mainly be attributed to differences in tree physiology at the two sites (that is, growth, water balance, phenology, and respiration), resulting from different climate conditions, the dominating tree functional type of the vegetation cover (coniferous vs. broad-leaved) and the age of the trees. The predominating influence of tree dynamics on the $\mathrm{CO}_{2}$ budget of the Davos forest was already shown in Zweifel and others (2010). They found a remarkably close relationship between NEE and continuously measured stem radius changes, which integrates growth and tree water relation processes. It was concluded that tree water relations and stem growth are representative for the productivity of the Davos forest, and that other ecosystem components, such as understory vegetation and SR, are acting most likely in phase with the measured trees.

SR was of similar magnitude at both sites despite different temperature conditions, due to higher temperature sensitivity of SR at the Davos forest (Figure 4), likely caused by the relatively high photosynthetic activity of the Davos conifers already under low temperature conditions (Figures 5,6) and coupled to this (Janssens and others 2001; Hoegberg and Read 2006) also high respiration rates. This pattern was confirmed by a larger belowground tree $\mathrm{C}$ pool and an increased belowground $\mathrm{C}$ allocation at the Davos forest compared to the Lägeren (Table 5). Similar observations were made at three Swiss forests of different altitudinal ranges (subalpine, montane, lowland). At the subalpine site, the lowest aboveground tree growth was measured, but the highest fine root $\mathrm{C}$ pool and the highest rates of root respiration (compare Graf Pannatier and others 2010). Thus, the importance of belowground tree processes apparently increases with increasing altitude.

\section{Uptake as a Function of Altitude?}

Valentini and others (2000) suggested respiration as the main determinant of the $\mathrm{C}$ balance of European forests. They found a decreased net uptake of European forests with increasing latitude, whereas GPP remained rather constant. We tested whether this hypothesis holds true also for increasing altitude, as the Alpine altitudinal gradient is often considered comparable to the latitudinal gradient of the Northern Hemisphere, for example, with respect to temperature (Koerner 1999), but with substantial differences, for example, in light intensity, day length, duration of the growth period, or soil temperature conditions. Figure 7 puts both sites in context with others compiled by Valentini and others (2000). During 2005-2009, the mean net uptake of the Davos forest was significantly lower compared to the Lägeren forest (Table 4). And whereas NEE of the Lägeren matches the regression line in Figure 7A nearly perfectly $\left(4.15 \mathrm{Mg} \mathrm{C} \mathrm{ha}^{-1} \mathrm{y}^{-1}\right.$ at $\left.47^{\circ} \mathrm{N}\right)$, NEE of Davos (1.17 Mg C ha $\mathrm{Mg}^{-1}$ at $46^{\circ} \mathrm{N}$ ) is not representative for its latitudinal range, but fits well
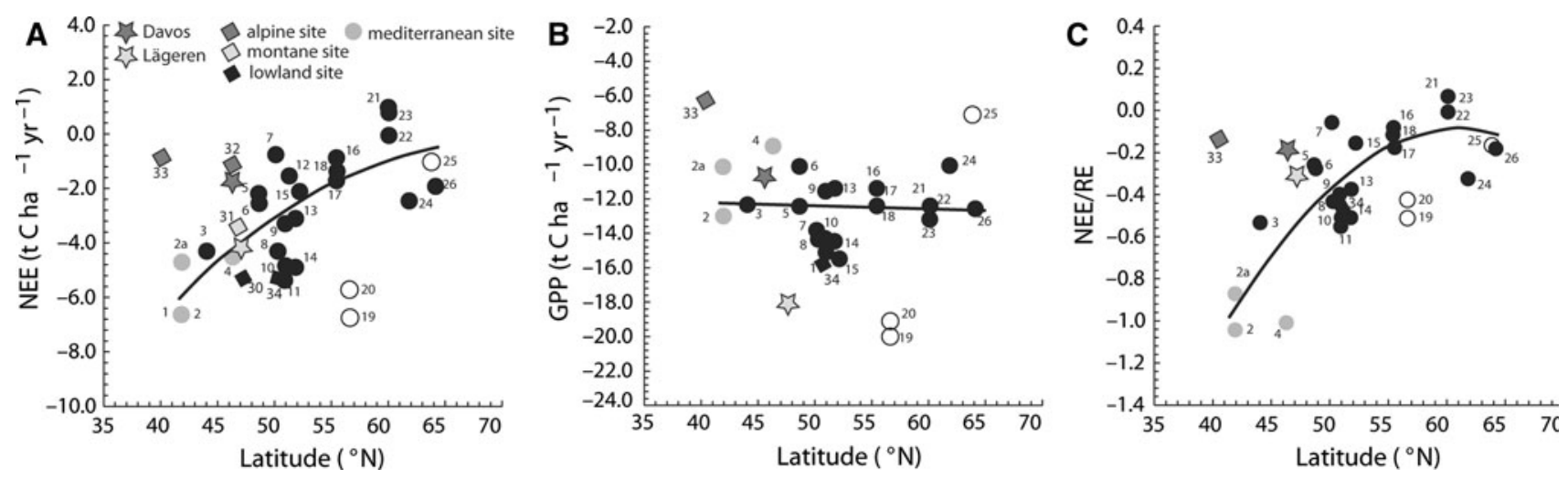

Figure 7. European forest $\mathrm{CO}_{2}$ budgets $(\operatorname{NEE}(\mathbf{A}), \mathrm{GPP}(\mathbf{B})$, and the ratio NEE/TER $(\mathbf{C}))$ as a function of latitude (modified from Figures. 1, 2, 3 in Valentini and others (2000); new mountain forests and/or Swiss forest sites are inserted as diamonds, the Lägeren and Davos sites as stars; Mediterranean mountain sites already included in Valentini and others (2000) were modified as gray circles). Open circles intensively managed plantations. The numbers $1-26$ are as in Valentini and others (2000). Added sites are: \#30 Vordemwald (480 m a.s.l, Switzerland); \#31 Schänis (730 m a.s.l., Switzerland); \#32 Beatenberg (1510 m a.s.l, Switzerland); \#33 Niwot Ridge (3050 m a.s.l., U.S.), \#34 Hainich (440 m a.s.l, Germany). Adapted by permission from Macmillan Publishers Ltd: Nature (Valentini and others), copyright (2000). Additional data were obtained from Graf Pannatier and others (2010) (\#30-32); Sacks and others (2007) (\#33); Knohl and others (2008) (\#34). 
in C budgets of forests north of $55^{\circ} \mathrm{N}$ (Figure 7A, see also Luyssaert and others 2007). This is also the case for other alpine forest sites in Switzerland (\#32 in Figure 7A) and outside Europe (\#33), whereas the Swiss montane forest site Schänis (\#31) is comparable to the Lägeren site. Mediterranean forests at higher altitudes $(\# 2,2 \mathrm{a}, 4)$, however, have a much higher net uptake compared to the alpine forests of the temperate zone and to lowland Mediterranean forests with NEE ranging from 90 to $551 \mathrm{~g} \mathrm{C} \mathrm{m}^{-2} \mathrm{y}^{-1}$ (compare Baldocchi and others 2010). An increasing net uptake with increasing altitude was also shown for ecosystems (desert, savannah, woodland, and forest) in southwestern North America by Anderson-Teixeira and others (2011). In these regions, the carbon uptake capacity of ecosystems at low altitudes is limited by hot and/or dry conditions, whereas subalpine ecosystems benefit from low temperatures and ample moisture. In contrast, the annual net uptake of subalpine forests in the temperate zone is mainly determined by the forest's spring net uptake capacity and the snow water availability during this period (Hu and others 2010).

Similarly, GPP at the Lägeren forest is much higher than at Davos (Figure 7B). Note that the carbon uptake by GPP is presented with a negative sign, and in this case most negative values mean a high carbon uptake by GPP. Whereas the Davos forest ranges among the sites with lowest GPP, the Lägeren forest has a higher mean GPP than most of the sites included in Valentini and others (2000). Although being large in this context, mean GPP (ca. $-1,800 \mathrm{~g} \mathrm{C} \mathrm{m}^{-2} \mathrm{y}^{-1}$ ) at the Lägeren is comparable to estimates for other forests in Europe not included in Valentini and others (2000), such as the old-growth beech forest Hainich in Germany $\left(-1670 \mathrm{~g} \mathrm{C} \mathrm{m}^{-2} \mathrm{y}^{-1}\right.$, Knohl and others 2003), the spruce forest Tharandt $\left(-1,845 \mathrm{~g} \mathrm{C} \mathrm{m}^{-2} \mathrm{y}^{-1}\right.$, Gruenwald and Bernhofer 2007) or a broad-leaved deciduous woodland in England $\left(-2,100 \mathrm{~g} \mathrm{C} \mathrm{m}^{-2}\right.$ $\mathrm{y}^{-1}$, Thomas and others 2011). In fact, Swiss forests, and especially those of the Central Plateau, to which the Lägeren borders, have been reported to be the most productive forests in Europe due to favorable growth conditions (SAEFL/WSL 2005; Braendli 2010). This is also reflected by tree sizes that reach a maximum of $42.2 \mathrm{~m}$ at the Lägeren (Eugster and others 2007). In comparison, GPP at Davos is rather low, but still significantly higher compared to the subalpine forest Niwot Ridge in the Colorado Rocky mountains (Figure 7B), which is explainable by the shorter growing period and the zero GPP during winter at the Niwot Ridge site (Sacks and others 2007). The ratio of NEE to TER of the Davos and Niwot Ridge site is in the same range, but higher than at the other forests at similar latitudes, indicating an increasing importance of respiration at higher altitudes (Figure 7C).

Differences between the forest $\mathrm{C}$ budgets at the Lägeren and at the Davos forests correspond to the latitudinal gradient found for the $\mathrm{C}$ balance of European forests, with altitude perceived as a proxy for changing environmental conditions, and an increasing tree age (SAEFL/WSL 2005). However, the relationship of NEE to altitude may not be the same for all vegetation zones and regions (for example, temperate, mediterranean, and tropical). This emphasizes the need to account for the altitudinal range of ecosystems in modeling approaches when aiming at a better understanding of forest ecophysiological processes, especially in response to climate change, which is predicted to be most pronounced in alpine regions.

\section{ACKNOWLEDGMENTS}

Meteorological data were made available through MeteoSwiss, Federal Office of Meteorology and Climatology, Switzerland and the Swiss air quality monitoring network (NABEL). We thank the forester Philip Vock for enabling and supporting the studies at the Lägeren forest, Johannes Böhm, Roger Süess, Arnold Streule and Thomas Baur for maintaining the EC infrastructure at Davos, as well as Lydia Gentsch for continuing the soil respiration measurements at the Lägeren in 2008. The study was funded by the ETH Zurich, Switzerland (ETH research grant TH-1006-02), and the Swiss Federal Office for Environment (BAFU Contract-No. 04.1140.PJ/I153-2413 and 06.0091.PZ/I153-2518).

\section{REFERENCES}

Altherr E, Unfried P, Hradetzky J, Hradetzky V. 1978. Statistische Rindenbeziehungen als Hilfsmittel zur Ausformung und Aufmessung unentrindeten Stammholzes, Teil IV. Mitteilungen der Forstlichen Versuchs-und Forschungsanstalt BadenWürttemberg 90:1-15.

Anderson-Teixeira KJ, Delong JP, Fox AM, Brese DA, Litvak ME. 2011. Differential response of production and respiration to temperature and moisture drive the carbon balance across a climatic gradient in New Mexico. Glob Change Biol 17: 410-24.

Appenzeller C, Beyert M, Zenklusen E, Scherrer SC. 2008. Monitoring climate at Jungfraujoch in the high Swiss Alpine region. Sci Total Environ 931:262-8.

Assmann SM. 1986. Zur theorie der grundflächenhaltung. Forstwiss Centralblatt 87:321-30.

Aubinet M. 2008. Eddy covariance $\mathrm{CO}_{2}$ flux measurements in nocturnal conditions: an analysis of the problem. Ecol Appl 18:1368-78. 
Aubinet M, Grelle A, Ibrom A, Rannik U, Moncrieff J, Foken T, Kowalski A, Martin PH, Berbigier P, Bernhofer C, Clement R, Elbers J, Granier A, Gruenwald T, Morgenstern K, Pilegaard K, Rebmann C, Snijders W, Valentini R, Vesala T. 2000. Estimates of annual net carbon and water exchange of forests: the EUROFLUX methodology. In: Fitter AH, Raffaelli D, Eds. Advances in ecological research. New York: Academic Press. p 113-75.

Aurela M, Laurila T, Tuovinen JP. 2002. Annual $\mathrm{CO}_{2}$ balance of a subarctic fen in northern Europe: importance of wintertime efflux. J Geophys Res 107. doi:10.1029/2002JD002055.

Baldocchi D. 2008. "Breathing" of the terrestrial biosphere: lessons learned from a global network of carbon dioxide flux measurement systems. Aust J Bot 56:1-26.

Baldocchi DD SM, Rambal S, Misson L, Ourcival JM, Limousin JM, Pereira J, Papale D. 2010. On the differential advantages of evergreeness and deciduousness in mediterranean oak woodlands: a flux perspective. Ecol Appl 20:1583-97.

Black K, Bolger T, Davis P, Nieuwenhuis M, Reidy B, Saiz G, Tobin B, Osborne B. 2007. Inventory and eddy covariancebased estimates of annual carbon sequestration in a Sitka spruce (Picea sitchensis (Bong.) Carr.) forest ecosystem. Eur J For Res 126:167-78.

Bolliger J, Hagedorn F, Leifeld J, Böhl J, Zimmermann S, Soliva R, Kienast F. 2008. Effects of land-use change on carbon stocks in Switzerland. Ecosystems 11:895-907.

Braendli UB. 2010. Schweizerisches landesforstinventar. Ergebnisse der dritten Erhebung 2004-2006 Birmensdorf, Eidgenössische Forschungsanstalt für Wald, Schnee und Landschaft WSL. Bern: Bundesamt für Umwelt BAFU.

Burba GG, McDermitt DK, Grelle A, Anderson DJ, Xu L. 2008. Addressing the influence of instrument surface heat exchange on the measurements of $\mathrm{CO}_{2}$ flux from open-path gas analyzers. Glob Change Biol 14:1854-76.

Chapin FS, Woodwell GM, Randerson JT, Rastetter EB, Lovett DK, Baldocchi DD, Clark DA, Harmon ME, Schimel DS, Valentini R, Wirth C, Aber JD, Cole JJ, Goulden ML, Harden JW, Heimann M, Howarth RW, Matson PA, Mc Guire AD, Melillo JM, Mooney HA, Neff JC, Houghton RA, Pace ML, Ryan MG, Running SW, Sala OE, Schlesinger WH, Schulze ED. 2006. Reconciling carbon-cycle concepts, terminology, and methods. Ecosystems 9:1041-50.

Curtis PS, Hanson PJ, Bolstad P, Barford C, Randolph JC, Schmid HP, Wilson KB. 2002. Biometric and eddy-covariance based estimates of annual carbon storage in five eastern North American deciduous forests. Agric For Meteorol 113:3-19.

de Wit HA, Palosuo T, Hylen G, Liski J. 2006. A carbon budget of forest biomass and soils in southeast Norway calculated using a widely applicable method. For Ecol Manag 225:15-26.

Desai AR, Richardson AD, Moffat AM, Kattge J, Hollinger DY, Barr A, Falge E, Noormets A, Papale D, Reichstein M, Stauch VJ. 2008. Cross-site evaluation of eddy covariance GPP and RE decomposition techniques. Agric For Meteorol 148:821-38.

Ehman JL, Schmid HP, Grimmond CSB, Randolph JC, Hanson PJ, Wayson CA, Cropley FD. 2002. An initial intercomparison of micrometeorological and ecological inventory estimates of carbon exchange in a mid-latitude deciduous forest. Glob Change Biol 8:575-89.

Ellenberg H, Leuschner C. 2010. Vegetation Mitteleuropas mit den Alpen: In ökologischer, dynamischer und historischer Sicht. Stuttgart: UTB.

Etzold S, Buchmann N, Eugster W. 2010. Contribution of advection to the carbon budget measured by eddy covariance at a steep mountain slope forest in Switzerland. Biogeosciences 7:1-15.

Eugster W, Kling G, Jonas T, McFadden JJ, Wuest A, MacIntyre S, Chapin FS. 2003. $\mathrm{CO}_{2}$ exchange between air and water in an Arctic Alaskan and midlatitude Swiss lake: importance of convective mixing. J Geophys Res 108: doi:10.1029/ 2002JD002653.

Eugster W, Senn W. 1995. A cospectral correction model for measurement of turbulent $\mathrm{NO}_{2}$ flux. Bound Layer Meteorol 74:321-40.

Eugster W, Zeyer K, Zeeman M, Michna P, Zingg A, Buchmann N, Emmenegger L. 2007. Methodical study of nitrous oxide eddy covariance measurements using quantum cascade laser spectrometry over a Swiss forest. Biogeosciences 4:1-13.

Farrar J, Hawes M, Jones D, Lindow S. 2003. How roots control the flux of carbon to the rhizosphere. Ecology 84: 827-37.

Gaudinski JB, Torn MS, Riley WJ, Dawson TE, Joslin JD, Majdi H. 2010. Measuring and modeling the spectrum of fine-root turnover times in three forests using isotopes, minirhizotrons, and the Radix model. Glob Biogeochem Cycles 24. doi: 10.1029/2009GB003649.

Goeckede M, Foken T, Aubinet M, Aurela M, Bernhofer C, Bonnefond JM, Brunet Y, Carrara A, Clement R, dellwik E, Elbers J, Eugster W, Fuhrer J, Granier A, Gruenwald T, Heinesch B, Janssens IA, Knohl A, Koeble R, Laurila T, Longdoz B, Manca G, Marek M, Markkanen T, Mateus J, Matteucci G, Mauder M, Migliavacca M, Minerbi S, Moncrieff J, Montagnani L, Moors E, Ourcival JM, Papale D, Pereira J, Pilegaard K, Pita G, Rambal S, Rebmann C, Rodrigues A, Rotenberg E, Sanz MJ, Sedlak P, Seufert G, Siebicke L, Soussana JF, Valentini R, Vesala T, Verbeeck H, Yakir D. 2008. Quality control of CarboEurope flux data-part 1: coupling footprint analyses with flux data quality assessment to evaluate sites in forest ecosystems. Biogeosciences 5:433-50.

Gough CM, Vogel CS, Schmid HP, Curtis PS. 2008a. Controls on annual forest carbon storage: lessons from the past and predictions for the future. Bioscience 58:609-22.

Gough CM, Vogel CS, Schmid HP, Su HB, Curtis PS. 2008b. Multiyear convergence of biometric and meteorological estimates of forest carbon storage. Agric For Meteorol 148:158-70.

Graf Pannatier E, Dobbertin M, Heim A, Schmitt M, Thimonier A, Waldner P, Frey B. 2010. Response of carbon fluxes to the 2003 heat wave and drought in three mature forests in Siwtzerland. Biogeochemistry. doi:10.1007/s10533-1001019554-y.

Gruenwald T, Bernhofer C. 2007. A decade of carbon, water and energy flux measurements of an old spruce forest at the Anchor Station Tharandt. Tellus 59B:387-96.

Heim A, Frey B. 2004. Early stage litter decomposition rates for Swiss forests. Biogeochemistry 70:299-313.

Heim A, Wehrli L, Eugster W, Schmid MWI. 2009. Effects of sampling design on the probability to detect soil carbon stock changes at the Swiss CarboEurope site Lägeren. Geoderma 149:347-54.

Hoegberg P, Read DJ. 2006. Towards a more plant physiological perspective on soil ecology. Trends Ecol Evol 21: 548-54.

Hollinger DY, Richardson AD. 2005. Uncertainty in eddycovariance measurements and its application to physiological models. Tree Physiol 25:873-85. 
Hu J, Moore DJP, Burns SP, Monson RK. 2010. Longer growing seasons lead to less carbon sequestration by a subalpine forest. Glob Change Biol 16:771-83.

IPCC. 2003. Good practice guidance for land use, land-use change and forestry. In: Penman J, Gytarsky M, Hiraishi T, Krug T, Kruger D, Pipatti R, Buendia L, Miwa K, Ngara T, Tanabe K, Wagner F, Eds. National Greenhouse Gas Inventories Programme, p 3.27.

IPCC. 2007. Climate change 2007: impacts, adaptation and vulnerability. contribution of working group II to the fourth assessmenat report of the intergovernmental panel on climate change In: Parry ML, Canziani OF, Palutikof JP, van der Linden PJ, Hanson CE, Eds. Cambridge, p 976.

IUSS Working Group WRB. 2007. World reference base for soil resourecs 2006 World Soil Resources Reports. Rome: FAO.

Jaervi L, Mammarella I, Eugster W, Ibrom A, Siivola E, Dellwik E, Keronen P, Burba G, Vesala T. 2009. Comparison of net $\mathrm{CO}_{2}$ fluxes measured with open- and closed-path infrared gas analyzers in an urban complex environment. Boreal Environ Res 14:499-514.

Janssens IA, Freibauer A, Ciais P, Smith P, Nabuurs GJ, Folberth G, Schlamadinger B, Hutjes RWA, Ceulemans R, Schulze ED, Valentini R, Dolman AJ. 2003. Europe's terrestrial biosphere absorbs 7 to $12 \%$ of European anthropogenic $\mathrm{CO}_{2}$ emissions. Science 300:1538-42.

Janssens IA, Lankreijer H, Matteucci G, Kowalski AS, Buchmann N, Epron D, Pilegaard K, Kutsch W, Longdoz B, Gruenwald T, Montagnani L, Dore J, Rebmann C, Moors EJ, Grelle A, Rannik U, Morgenstern K, Oltchev S, Clement R, Gudmundsson J, Minerbi S, Berbigier P, Ibrom A, Moncrieff J, Aubinet M, Bernhofer C, Jensen NO, Vesala T, Granier A, Schulze ED, Lindroth A, Dolman AJ, Jarvis AJ, Ceulemans R, Valentini R. 2001. Productivity overshadows temperature in determining soil and ecosystem respiration across European forests. Glob Change Biol 7:269-78.

Jörg S. 2008. Böden im Seehornwald bei Davos und deren Vorrat an Kohlenstoff und Stickstoff. Unpublished Thesis. Diploma thesis.

Kaufmann E. 2001. Estimating of standing timber, growth and cut. In: Brassel P, Lischke H, Eds. Swiss National Forest Inventory: methods and models of the second assessment. Birmensdorf: Swiss Federal Institute WSL. p 162-96.

Keith H, Leuning R, Jacobsen KL, Cleugh HA, Van Gorsel E, Raison RJ, Medlyn BE, Winters A, Keitel C. 2009. Multiple measurements constrain estimates of net carbon exchange by a Eucalyptus forest. Agric For Meteorol 149:535-58.

Kindler R, Siemens J, Kaiser K, Walmsley DC, Bernhofer C, Buchmann N, Cellier P, Eugster W, Gleixner G, Gruenwald T, Heim A, Ibrom A, Jones SK, Jones M, Klumpp K, Kutsch W, Steenberg Larsen K, Lehuger S, Loubet B, McKenzie R, Moors E, Osborne B, Pilegaard K, Rebmann C, Saunders M, Schmidt MWI, Schrumpf M, Seyfferth J, Skiba U, Soussana JF, Sutton MA, Tefs C, Vowinckel B, Zeeman MJ, Kaupenjohann M. 2011. Dissolved carbon leaching from soil is a crucial component of the net ecosystem carbon balance. Glob Change Biol 17:1167-85.

Kljun N, Calanca P, Rotach MW, Schmid HP. 2004. A simple parameterisation for flux footprint predictions. Bound Layer Meteorol 112:503-23.

Knohl A, Schulze E-D, Kolle O, Buchmann N. 2003. Large carbon uptake by an unmanaged 250-year-old deciduous forest in Central Germany. Agric For Meteorol 118:151-67.
Knohl A, Soe ARB, Kutsch WL, Goeckede M, Buchmann N. 2008. Representative estimates of soil and ecosystem respiration in an old beech forest. Plant Soil 302:189-202.

Koerner C. 1999. Alpine plant life. Functional plant ecology of high mountain ecosystems. Berlin, Heidelberg, New York: Springer.

Kominami Y, Jomura M, Dannoura M, Yoshiaki G, Tamai K, Takafumi M, Yoichi K, Kaneko S, Okumura M, Misawa N, Hamada S, Sasaki T, Kimura H, Ohtani Y. 2008. Biometric and eddy-covariance-based estimates of carbon balance for a warmtemperate mixed forest in Japan. Agric For Meteorol 148:723-37.

Kowalski AS, Serrano-Ortiz P, Janssens IA, Sanchez-Moral S, Cuezva S, Domingo F, Were A, Alados-Arboledas L. 2008. Can flux tower research neglect geochemical $\mathrm{CO}_{2}$ exchange? Agric For Meteorol 148:1045-54.

Liptzin D, Williams MW, Helming D, Seok B, Filippa G, Chowanski K, Hueber J. 2009. Process-level controls on $\mathrm{CO}_{2}$ fluxes from a seasonally snow-covered subalpine meadow soil, Niwot Ridge, Colorado. Biogeochemistry 95:151-66.

Liski J, Perruchoud D, Karjalainen T. 2002. Increasing carbon stocks in the forest soils of Western Europe. For Ecol Manag 169:159-75.

Liski J, Tuomi M, Rasinmaeki J. 2009. Yasso07 user-interface manual.

Lloyd J, Taylor JA. 1994. On the temperature dependence of soil respiration. Funct Ecol 8:315-23.

Loewe H, Seufert G, Raes F. 2000. Comparison of methods used within Member States for estimating $\mathrm{CO}_{2}$ emissions and sinks according to UNFCCC and EU monitoring mechnism: forest and other wooded land. Biotechn Agron Soc Environ 4:315-19.

Luescher UP. 1991. Humusbildung und Humuswandlung in Waldbeständen. Unpublished Thesis. ETH PhD. doi:10.3929/ ethz-a-000619069.

Luyssaert S, Inglima I, Jung M, Richardson AD, Reichstein M, Papale D, Piao SL, Schulze ED, Wingate L, Matteucci G, Bonal D, Bonnefond M, Chambers J, Ciais P, Cook B, Davis KJ, Dolman AJ, Gielen B, Goulden M, Grace J, Granier A, Grelle A, Griffis T, Gruenwald T, Guidolotti G, Hanson PJ, Harding R, Hollinger DY, Hutyra LR, Kolari P, Kruijt B, Kutsch W, Lagergren F, Laurila T, Law BE, Le Maire G, Lindroth A, Loustau D, Malhi Y, Mateus J, Migliavacca M, Misson L, Montagnani L, Moncrieff J, Moors E, Munger JW, Nikinmaa E, Ollinger SV, Pita G, Rebmann C, Roupsard O, Saigusa N, Sanz MJ, Seufert G, Sierra C, Smith ML, Tang J, Valentini R, Vesala T, Janssens IA. 2007. $\mathrm{CO}_{2}$ balance of boreal, temperate, and tropical forests derived from a global database. Glob Change Biol 13:2509-37.

Luyssaert S, Reichstein M, Schulze ED, Janssens IA, Law BE, Papale D, dragoni D, Goulden ML, Granier A, Kutsch W, Linder S, Matteucci G, Moors E, Munger JW, Pilegaard K, Saunders M, Falge EM. 2009. Toward a consistency crosscheck of eddy covariance flux-based and biometric estimates of ecosystem carbon balance. Glob Biogeochem Cycles 23. doi:10.1029/2008GB003377.

Mauder M, Foken T, Clement R, Elbers JA, Eugster W, Gruenwald T, Heusinkveld B, Kolle O. 2008. Quality control of CarboEurope flux data-part II: inter-comparison of eddycovariance software. Biogeosci Discus 4:4067-99.

McDowell N, Marshall J, Hocker T, Musselman R. 2000. Estimating $\mathrm{CO}_{2}$ flux from snowpacks at three sites in the Rocky Mountains. Tree Physiol 20:745-53. 
MeteoSwiss. 2010. [online] URL: http://www.meteoswiss.admin. ch/web/en/weather.html, http://www.meteoswiss.admin.ch/ web/en/climate/observation_systems/surface.html.

Metzger MJ, Bunce RGH, Leemans R, Viner D. 2008. Projected environmental shifts under climate change: European trends and regional impacts. Environ Conserv 35:64-75.

Moffat AM. 2010. A new methodology to interpret high resolution measurements of net carbon fluxes between the terrestrial ecosystems and the atmosphere. Unpublished $\mathrm{PhD}$ Thesis, Schiller University, Jena.

Monson RK, Burns SP, Williams MW, Delany AC, Weintraub M, Lipson DA. 2006. The contribution of beneath-snow soil respiration to total ecosystem respiration in a high-elevation, subalpine forest. Glob Biogeochem Cycles 20:1-13.

Monson RK, Sparks JP, Rosenstiel TN, Scott-Denton LE, Huxman TE, Harley PC, Turnipseed AA, Burns SP, Backlund B, Hu J. 2005. Climatic influences on net ecosystem $\mathrm{CO}_{2}$ exchange during the transition from wintertime carbon source to springtime carbon sink in a high-elevation, subalpine forest. Oecologia 146:130-47.

NABEL. 2010. http://www.bafu.admin.ch/luft/00612/00625/ index.html.

Ohtsuka T, Saigusa N, Koizumi H. 2009. On linking multiyear biometric measurements of tree growth with eddy covariancebased net ecosystem production. Glob Change Biol 15:1015-24.

Peichl M, Brodeur JJ, Khomik M, Arain MA. 2010. Biometric and eddy-covarinace-based estimates of carbon fluxes in an age-sequence of temperate pine forests. Agric For Meteorol 150:952-65.

Perruchoud D, Kienast F, Kaufmann E, Braker O. 1999. 20th century carbon budget of forest soils in the Alps. Ecosystems 2:320-37.

Reichstein M, Falge E, Baldocchi D, Papale D, Aubinet M, Berbigier P, Bernhofer C, Buchmann N, Gilmanov T, Granier A, Gruenwald T, Havrankova K, Ilvesniemi H, Janous D, Knohl A, Laurila T, Lohila A, Loustau D, Matteucci G, Meyers T, Miglietta F, Ourcival JM, Pumpanen J, Rambal S, Rotenberg E, Sanz M, Tenhunen J, Seufert G, Vaccari F, Vesala T, Yakir D, Valentini R. 2005. On the separation of net ecosystem exchange into assimilation and ecosystem respiration: review and improved algorithm. Glob Change Biol $11: 1424-39$

Richardson AD, Hollinger DY, Aber JD, Ollinger SV, Braswell BH. 2007. Environmental variation is directly responsible for short but not long-term variation in forest-atmosphere carbon exchange. Glob Change Biol 13:788-803.

Ruehr NK, Buchmann N. 2010. Soil respiration fluxes in a temperate mixed forest: seasonality and temperature sensitivities differ among microbial and root-rhizosphere respiration. Tree Physiol 30:165-76.

Ruehr NK, Knohl A, Buchmann N. 2010. Environmental variables controlling soil respiration on diurnal, seasonal and annual time-scales in a mixed mountain forest in Switzerland. Biogeochemistry 98:153-70.

Sacks WJ, Schimel D, Monson RK. 2007. Coupling between carbon cycling and climate in a high-elevation, subalpine forest: a model-data fusion analysis. Oecologia 151: $54-68$.

SAEFL/WSL. 2005. Forest report 2005-facts and figures about the condition of Swiss forests. Berne: Swiss Federal Agency for the Environment, Forest and Landscape; Birmensdorf: Swiss Federal Research Institute WSL.
Schindlbacher A, Zechmeister-Boltenstern S, Glatzel G, Jandl R. 2007. Winter soil respiration from an Austrian mountain forest. Agric For Meteorol 146:205-15.

Schroeter D, Cramer W, Leemans R, Prentice IC, Araujo MB, Arnell NW, Bondeau A, Bugmann H, Carter TR, Gracia CA, Vega-Leinert dl AC, Erhard M, Ewert F, Glendining M, House JI, Kankaanpaeae S, Klein RJT, Lavorel S, Lindner M, Metzger MJ, Meyer J, Mitchell TD, Reginster I, Rounsevell M, Sabate S, Sitch S, Smith B, Smith J, Smith P, Sykes MT, Thonicke K, Thuiller W, Tuck G, Zaehle S, Zierl B. 2005. Ecosystem service supply and vulnerability to global change in Europe. Science 310:1333-7.

Serrano-Ortiz P, Roland M, Sanchez-Moral S, Janssens IA, Domingo F, Godderis Y, Kowalski AS. 2010. Hidden, abiotic $\mathrm{CO}_{2}$ flows and gaseous reservoirs in the terrestrial carbon cycle: review and perspectives. Agric For Meteorol 150:321-9.

Smith S, Read D. 1997. Mycorrhizal symbiosis. San Diego (CA): Academic Press.

Thomas MV, Malhi Y, Fenn KM, Fisher JB, Morecroft MD, Lloyd CR, Taylor ME, McNeil DD. 2011. Carbon dioxide fluxes over an ancient broadleaved deciduous woodland in southern England. Biogeosciences 8:1595-613.

Thuerig E, Palosuo T, Bucher J, Kaufman E. 2005. The impact of windthrow on carbon sequestration in Switzerland: a modelbased assessment. For Ecol Manag 210:337-50.

Thuerig E, Schmid S. 2008. Jährliche $\mathrm{CO}_{2}$-flüsse im wald: berechnungsmethode für das treibhausgasinventar. Schweiz Z Forstwes 159:31-8.

Tuomi M, Thum T, Jarvinen H, Fronzek S, Berg B, Harmon M, Trofymow JA, Sevanto S, Liski J. 2009. Leaf litter decomposition-estimates of global variability based on Yasso07 model. Ecol Model 220:3362-71.

UNEP-WCMC. 2009. [online] URL: http://www.unep-wcmc.org.

Valentini R, Matteucci G, Dolman AJ, Schulz E-D, Rebmann C, Moors EJ, Granier A, Gross P, Jensen NO, Pilegaard K, Lindroth A, Grelle A, Bernhofer C, Gruenwald T, Aubinet M, Ceulemans R, Kowalski A, Vesala T, Rannik U, Berbigier P, Loustau D, Gudmundsson J, Thorgeirsson H, Ibrom A, Morgenstern K, Clement R, Moncrieff J, Montagnani L, Minerbi S, Jarvis PG. 2000. Respiration is the main determinant of carbon balance in European forests. Nature 404:861-5.

Vavrova P, Pentilla T, Laiho R. 2009. Decomposition of Scots pine fine woody debris in boreal conditions: implications for estimating carbon pools and fluxes. For Ecol Manag 257:401-12.

Webb EK, Pearman GI, Leuning R. 1980. Correction of flux measurements for density effects due to heat and water vapour transfer. Q J R Met Soc 106:85-100.

Wirth C, Schumacher J, Schulze ED. 2004. Generic biomass functions for Norway spruce in Central Europe-a met-analysis approach toward prediction and uncertainty estimation. Tree Physiol 24:121-39.

Wutzler T, Wirth C, Schumacher J. 2008. Generic biomass functions for common beech (Fagus sylvatica) in Central Europe: predictions and components of uncertainty. Can J For Res 38:1661-75.

Zweifel R, Eugster W, Etzold S, Dobbertin M, Buchmann N, Häsler R. 2010. Link between continuous stem radius changes and net ecosystem productivity of a subalpine Norway spruce forest in the Swiss Alps. New Phytol 187:819-30.

Zweifel R, Haesler R. 2001. Dynamics of water storage in mature subalpine Picea abies: temporal and spatial patterns of change in stem radius. Tree Physiol 21:561-9. 